\title{
Article \\ Provenance of Jurassic Sediments from Yuqia Sandstone-Type Uranium Deposits in the Northern Margin of Qaidam Basin, China and Its Implications for Uranium Mineralization
}

\author{
Guangwen Huang ${ }^{1}$, Dehai $\mathrm{Wu}^{2}{ }^{2} * \mathbb{0}$, Guangnan Huang ${ }^{3}$, Wanwen Xue ${ }^{4}$, Zhuang Min ${ }^{1}$ and Pengfei Fan ${ }^{1}$ \\ 1 School of Earth Sciences, East China University of Technology, Nanchang 330013, China; \\ 2020010005@ecut.edu.cn (G.H.); MinZ@ecut.edu.cn (Z.M.); fanpf2021@163.com (P.F.) \\ 2 School of Resources, Environment and Jewelry, Jiangxi College of Applied Technology, \\ Ganzhou 341000, China \\ 3 No.105 Exploration Team, Qinghai Bureau of Coal Geological Exploratio, Xining 810007, China; \\ gnhuang1989@163.com \\ 4 Key Laboratory of the Northern Qinghai-Tibet Plateau Geological Processes and Mineral Resources, \\ Xining 810012, China; wwxue810012@163.com \\ * Correspondence: dehaiwu@163.com
}

Citation: Huang, G.; Wu, D.; Huang, G.; Xue, W.; Min, Z.; Fan, P.

Provenance of Jurassic Sediments from Yuqia Sandstone-Type Uranium Deposits in the Northern Margin of Qaidam Basin, China and Its Implications for Uranium

Mineralization. Minerals 2022, 12, 82. https://doi.org/10.3390/min12010082 Academic Editors: Alexander Malov, Oleg S. Pokrovsky and

Jaromír Leichmann

Received: 14 November 2021

Accepted: 4 January 2022

Published: 11 January 2022

Publisher's Note: MDPI stays neutral with regard to jurisdictional claims in published maps and institutional affiliations.

Copyright: (c) 2022 by the authors. Licensee MDPI, Basel, Switzerland. This article is an open access article distributed under the terms and conditions of the Creative Commons Attribution (CC BY) license (https:// creativecommons.org/licenses/by/ $4.0 /)$.

\begin{abstract}
The Yuqia uranium deposit is a newly discovered sandstone-type uranium deposit in the northern margin of the Qaidam Basin. Concerning the sources of sediment in the basin, most scholars have focused on the study of Cenozoic sediment sources in the northern part of the basin, rather than on the study of Jurassic provenance and its implications for uranium mineralization. In this paper, the Jurassic sandstones in the area were selected for petrography, petrogeochemistry and electron microprobe analysis (EPMA), and the significance of sedimentary provenance and uranium metallogeny were further discussed, based on the previous data of detrital zircon chronology. It is reported here for the first time that coffinite and pitchblende are the main contributors. Independent uranium minerals in the region mainly occur in strawberry pyrite, xenotime, and margins or of quartz. The rocks in the source area, Jurassic sandstones, were mainly formed under the tectonic setting of the active continental margin; however, the sediments are mainly derived from the Indosinian and Paleozoic granitoids exposed in the northern margin of the Qaidam Basin. The uranium-rich granites in the source area led to the preconcentration of uranium in the sandstone of the target layer, and the uranium was brought into the ore-bearing target layer through uranium-bearing oxygenated water. The reduction reaction occurred under the action of reducing matter, and finally, the $\mathrm{U}^{6+}$ was reduced to $\mathrm{U}^{4+}$ in the formation of coffinite and pitchblende.
\end{abstract}

Keywords: provenance analysis; element geochemistry; sandstone-type uranium deposit; Qaidam Basin

\section{Introduction}

The Qaidam Basin is one of the most important ore-bearing basins in Northwestern China, abounding in multiple resources such as coal, sylvite, oil, natural gas, and uranium. The formation and evolution of the Qaidam Basin are inseparable from the intense activities in the Tethys-Himalayan tectonic zone [1-3]. The northern margin of the basin is located among the units of the northern Qaidam tectonic belt, the Qilian Mountain tectonic belt, and the Altun Mountain tectonic belt. It is an important area where the tectonic zones of the Paleo-Asian Ocean and Tethys converged [1-5]; still, its past experiences of intense tectonic movements for multiple periods have caused certain difficulties regarding the recovery of provenance, as well as numerous uncertainties as to the prediction of sandstonetype uranium deposits in the basin. Clastic sediments are one of the most important criteria for identifying the tectonic backgrounds of sedimentary basins, the evolution of intracontinental basins, and the nature of source rocks in provenance areas [6-8]. Sandstonetype uranium deposits have obvious characteristics in terms of sandstones controlled by 
sedimentary facies and ores controlled by the sandstone body [8]. Therefore, study on the provenance of sand bodies is an essential prerequisite for the prospecting of sandstone-type uranium deposits.

The northern margin of the Qaidam Basin has evolved as a composite structure with different rock types formed in different geodynamic processes, and its orogenic clasts represent a variety of characteristics $[9,10]$. Until now, more scientists have focused on the Cenozoic sedimentary provenances and tectonic evolution in the northern and central Qaidam Basin [10-16]. However, only a few scientists have studied the Jurassic provenance in the northern margin of the basin from the perspective of detrital zircon $\mathrm{U}-\mathrm{Pb}$ chronology [3,17]. So far, the research on sedimentary provenance is inadequate, while details of the nature and characteristics of the source rocks obtained by our predecessors merely from detrital zircon chronology are relatively scant. Corresponding analyses on geochemical characteristics are also required to provide evidence for further specifying source characteristics. Secondly, information on the sandstone types of uranium mineralization has been found in succession, from Yuqia, Tuanyushan, and other areas in the northern margin of the basin, on a certain scale, from the ore-bearing horizon of the Middle Jurassic Shimengou Formation. The lack of research on provenance and uranium mineralization has partially restricted further exploration on sandstone-type uranium deposits in the region. Judging from field outcrops and borehole exposure, there are relatively perfect Jurassic strata in the Yuka area. Sand bodies are uniformly distributed in each stratum, without undergoing significant epigenetic alteration. The sandstone-type uranium mineralization in the area is massive, offering promising prospecting potential. The "mud-sand-mud" strata with a stable structure are typical characteristics of a sandstone-type uranium deposit that has undergone interlayer oxidation. Compared with those in the Tuanyushan and Lvcaoshan areas in the northern margin of the basin, these sandstone-type uranium deposits are more representative in the Yuka area. In addition, many studies have shown that the petrographic characteristics and trace elements $(\mathrm{La}, \mathrm{Th}, \mathrm{Sc}, \mathrm{Zr}, \mathrm{Hf}$, and $\mathrm{Eu})$ of clastic rocks may reflect the composition and tectonic setting of the source rocks $[18,19]$. Therefore, this paper systematically samples the Jurassic sandstones exposed by drilling in the Yuqia uranium mining areas, and studies them via petrological and geochemical means and electron-probe microanalysis, combining this with the previous chronological data about detrital zircons. It is expected that these provenance characteristics and uranium metallogenesis will provide an essential theoretical basis for the further prospecting of sandstone-type uranium deposits in the region.

\section{Geological Setting}

As a Mesozoic-Cenozoic intracontinental basin, the Qaidam Basin is located in Qinghai Province, on the northeastern margin of the Qinghai-Tibet Plateau (Figure 1a), bounded by the East Kunlun Mountain tectonic belt in the south, by the Altun Fault in the west, and by the Qilian Mountains in the north by its northern-margin tectonic belt [1-3]. From west to east in the northern margin of the basin, there are multiple sandstone-type uranium occurrences, such as at Lenghu, Tuanyushan, Yuqia and Lvcaoshan (Figure 1b), all of which belong to the interlayer oxidation zone of sandstone uranium. Among them, the Yuqia uranium occurrence is located in the secondary tectonic unit of the Yuqia-Hongshan fault depression in the central part of the northern margin of the Qaidam Basin, with Dakendaban Mountain in the north and east of Yuqia, and Lvliang Mountain in the south. It is also adjacent to Mount Saishten in the west and bounded by the Maxian Fault in the southwest, with an average elevation of $3050 \mathrm{~m}$ and total coverage of $430 \mathrm{~km}^{2}[19,20]$. The area is obviously affected by fold structures and faults, with many anticlines and synclines, such as the Yuqia anticline and syncline, the Gaxiu anticline, and the Jiulongshan anticline. Reverse faults are widely formed in the area toward the NWW (Figure 1c). Drilling in the area revealed that the Jurassic strata in the area have been successively formed from bottom to top, including the Middle Jurassic Shimenggou Formation $\left(\mathrm{J}_{2} \mathrm{~s}\right)$ and Upper Jurassic Caishiling Formation (Figure 2). The field outcrops show that the Shimengou Formation 
is in parallel but with an irregular contact with the Caishiling Formation (Figure 3a). The Upper Jurassic is generally a set of continental variegated clastic sedimentary rocks (Figure 3b), with mudstone sediments in parts. The middle-lower Jurassic Series is a set of fluvial and lacustrine-swamp facies of grey-green-yellow coal-bearing clastic rock sediments (Figure 3c), serving as an important coal bed and hydrocarbon source bed in the basin, as well as an important prospecting target bed in the area [1,21-24]. Small-sized areas of carnotite with secondary uranium mineralization are exposed on the surface in some outcrops (Figure 3d). In addition, the Cretaceous system was greatly uplifted and denuded in later periods. Only the Quanyagou Formation of the Lower Cretaceous Series remains sporadic in local outcrops $[17,21]$. The Paleogene, Neogene, and Quaternary Series are dominated by fluvial deposits, leading to the red and variegated sedimentary formations. Through field outcrops and drilling verification, it has been found that the sandstone-type uranium mineralization in the Yuqia area is concentrated in the yellowgreen gritstones at the front line of the oxidation-reduction transitional zone. The ore bodies are distributed in a roll shape (Figure 2), with a stable "mud-sand-mud" structure and good permeability in general, and the ore-bearing horizon consists of the Shimengou Formation of the Middle Jurassic.

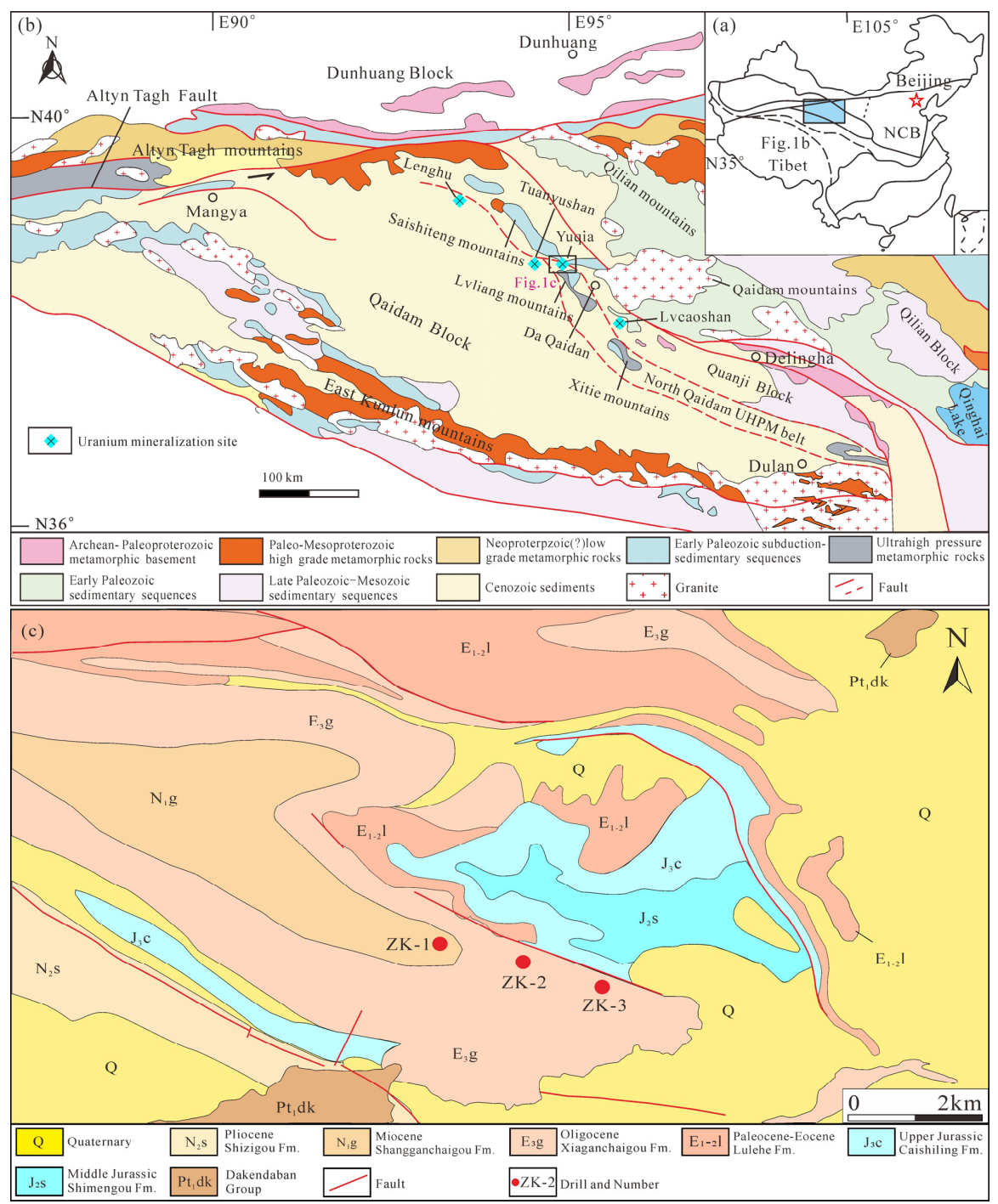

Figure 1. (a) A sketch map of the northern margin of the Qaidam Basin, China; (b) a geological map of the Qaidam Basin, showing well-developed structures, magmatic and metamorphic rocks, sedimentary units, and known uranium mineralization sites (modified after Yan et al. [20]); (c) a geological sketch of the Yuqia uranium deposits (modified after Lian et al. [21]). 


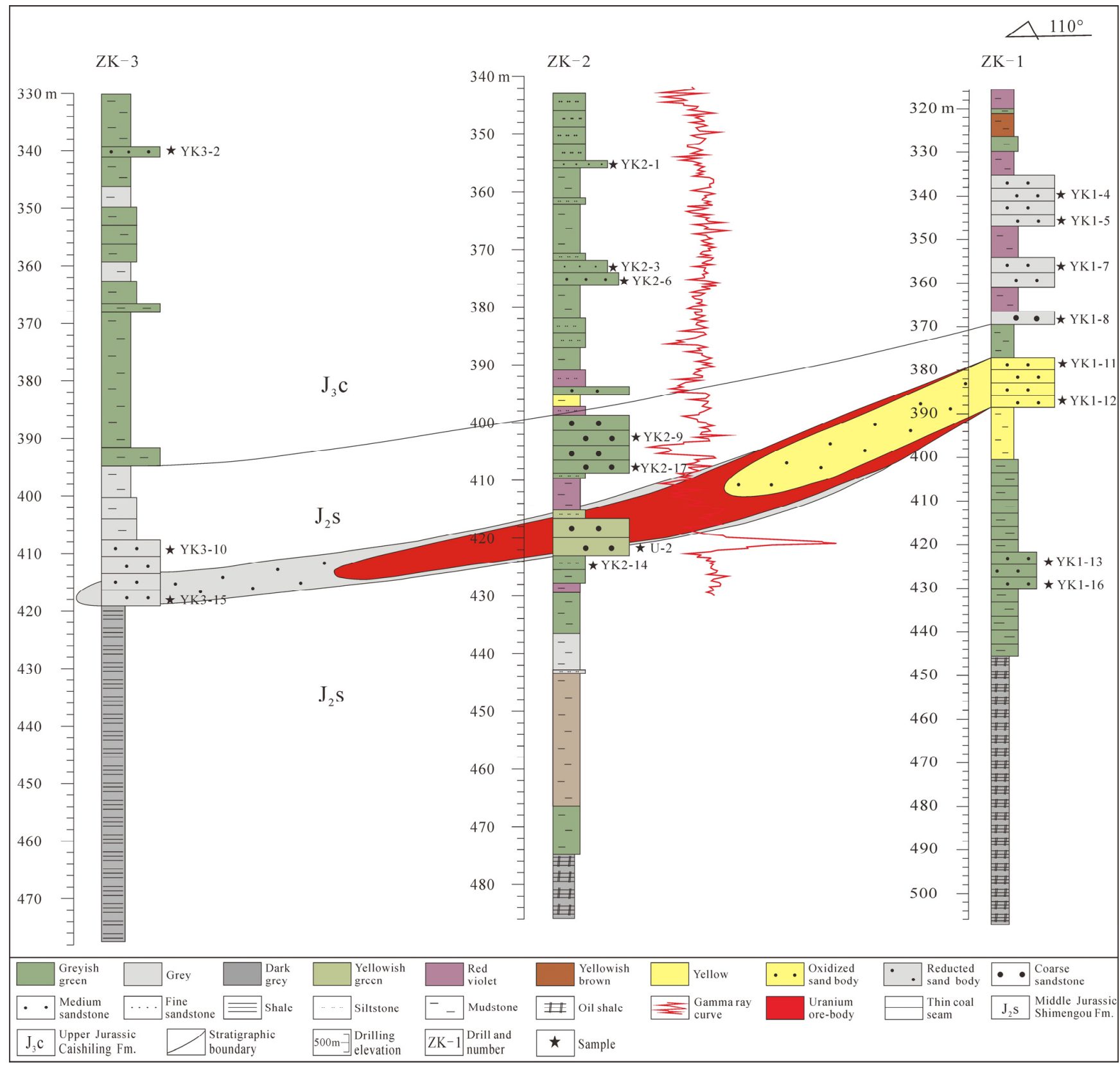

Figure 2. A drilling section of Yuqia sandstone-type uranium deposits. 

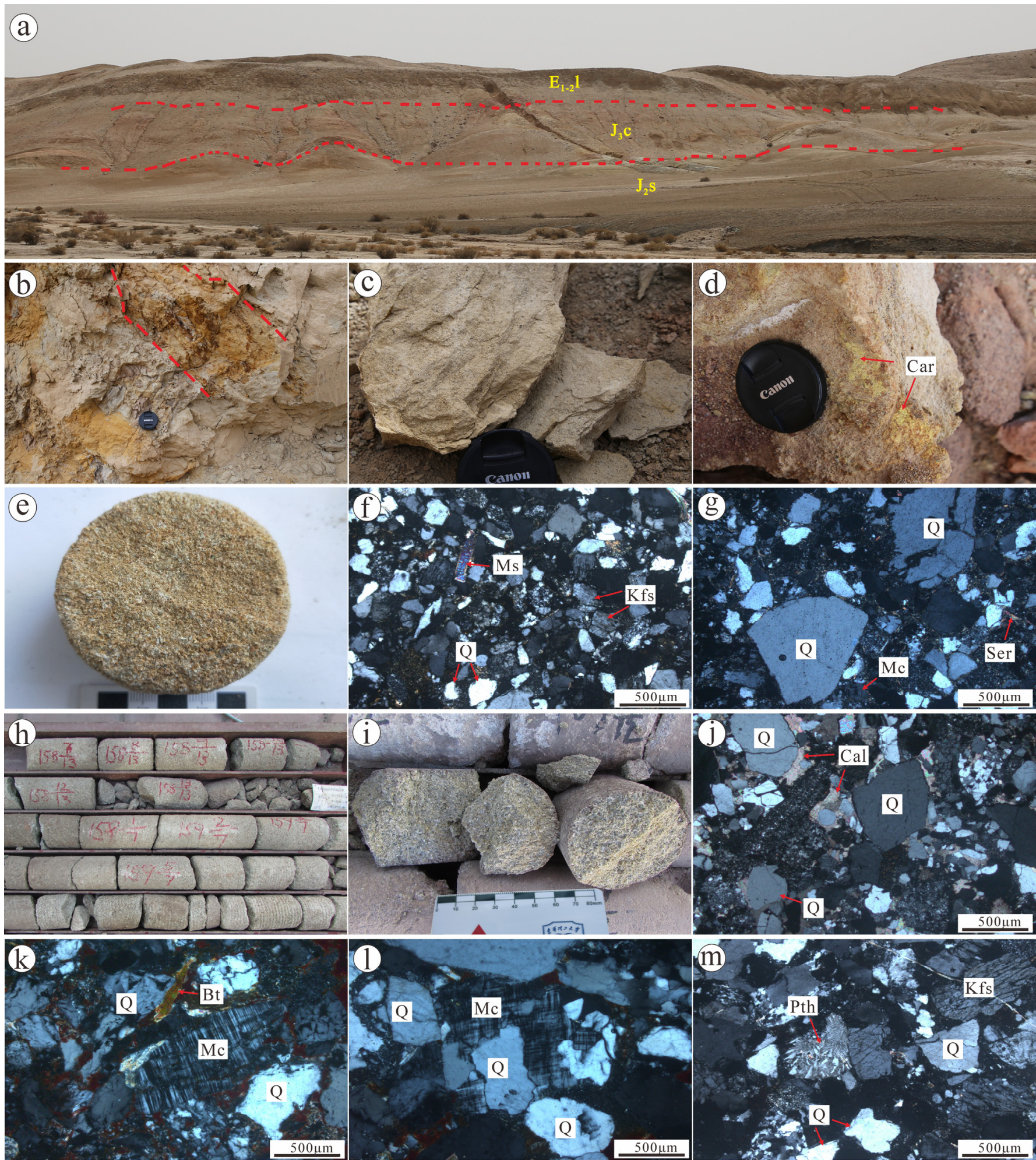

Figure 3. Characteristics of Jurassic sandstone outcrops and petrography of representative samples in Yuqia uranium ore fields. (a) Field outcrops of the Paleo-Eocene Lulehe Formation $\left(E_{1}-21\right)$, Upper Jurassic Caishiling Formation $\left(\mathrm{J}_{3} \mathrm{c}\right)$, and Middle Jurassic Shimengou Formation $\left(\mathrm{J}_{2} \mathrm{~s}\right)$; $(\mathbf{b})$ variegated sandstones of the Upper Jurassic Caishiling Formation; (c) yellow-green sandstones of the Shimengou Formation of the Middle Jurassic; (d) secondary uranium mineral carnotites in sandstones of Shimengou Formation; (e) pale yellow sandstones of the Caishiling Formation exposed by drilling; (f) the sandstones with a sandy texture of the Caishiling Formation; (g) an irregularly corroded quartz 
edge with an obvious intracrystalline fragmentation; (h) the Shimengou Formation, exposed by drilling;(i) the Shimengou Formation ore-bearing yellow-green gritstones; (j) the sandstones in the sandy textures of the Shimengou Formation; (k) the obvious development of "explosive cracks" in quartz; (1) the granite debris; (m) the striped texture developed by the striped feldspar in the granite debris and the melted quartz edge. Abbreviations: Q, quartz; Mc, microcine; Bt, biotite; Ms, muscovite; Pl, plagioclase; Kfs, K-feldspar; Pth, perthite; Ptc, pitchblende; Chl, chlorite; Car, carnotite.

\section{Sampling and Analytical Methods}

The Jurassic sandstones exposed by the drilled holes (one uranium-industry hole and two mineralized holes) in the Yuqia uranium deposits in the northern margin of the Qaidam Basin were sampled, and 18 representative sandstone samples were selected for research (Figure 2). Of these, 8 of them were variegated medium- to fine-grained sandstones of the Caishiling Formation $\left(\mathrm{J}_{3} \mathrm{c}\right)$ and the remaining 10 were of the yellow-green coarse-grained sandstones of the Shimengou Formation $\left(\mathrm{J}_{2} \mathrm{~s}\right)$.

The collected Jurassic sandstone samples were ground into groups of rock slices and the detrital components of sandstone, to be tested using the Gazzi-Dickinson microscope statistical method [18]. The sampling points in the section images were counted with the linear counting method, using an eyepiece scale as the sampling tool at a microscope scale calibrated by a stage micrometer; then, the image was measured and analyzed through the microscope. The average number of grains from the slices of each sandstone sample was estimated to be 300, and finally, the Dickinson diagram was used to analyze the source characteristics.

The analysis of major elements, trace elements, and rare earth elements of sandstone samples is completed by Aoshi Analysis and Testing (Guangzhou) Co., Ltd. (Guangzhou, China). The main elements are analyzed with an X-ray fluorescence spectrometer (XRF), using an XRF-1800 X-ray fluorescence spectrometer, and the analytical error was controlled to within the limit of $\pm 5 \%$. The trace elements and rare earth elements were analyzed using the ICP-MS method, the instrument being a Thermo Fisher X Series II model quadrupole inductively coupled plasma mass spectrometer, made in the US. The analytic error was estimated to be less than $5 \%$ when the relative content of trace elements was over $10 \times 10^{-6}$, and less than $10 \%$ when the relative content was under $10 \times 10^{-6}$. The method described by Chen et al. (2000) [25] was referenced for the chemical assay procedure.

EPMA slices were created by grinding the selected representative ore-bearing sandstones, and the chemical compositions of the uranium mineral were analyzed in the electron probe room of the State Key Laboratory of Nuclear Resources and Environment, East China University of Technology. An Inca Energy spectrometer, coupled with a JXA-8100M electron probe, was used as the instrument for this analysis. The test conditions are detailed as follows: accelerating voltage $15.0 \mathrm{kV}$, beam current $20.0 \mathrm{nA}$, beam spot diameter $2 \mu \mathrm{m}$, and correction method ZAF [26]. The test process was carried out in strict conformity with the national standard (GB/T 15617-2002) [27]. The following standard samples were used in the test: $\mathrm{U}-\mathrm{UO}_{2}, \mathrm{Y}$-almandine, Th-thorianite, $\mathrm{Pb}-\mathrm{PbCr}_{2} \mathrm{O}_{4}$, Ce-synthetic rare-earth pentaphosphate, $\mathrm{Nd}$-synthetic rare-earth pentaphosphate, $\mathrm{Ca}$-bustamite, $\mathrm{Fe}-\mathrm{Fe}_{2} \mathrm{O}_{3}$, Si-Albite, etc.

\section{Analysis Results}

\subsection{Petrographic Characteristics}

The sandstones revealed in the Caishiling Formation $\left(\mathrm{J}_{3} \mathrm{c}\right)$ are light yellow, mainly medium (fine)-grained (Figure 3e), with a sandy composition (Figure 3f) and massive structure. The monomicts are mainly composed of quartz, feldspar, and lithic clast, and their particle sizes are mainly centralized within $0.12 \mathrm{~mm} \sim 0.28 \mathrm{~mm}$. Gravels (mainly composed of single-crystal quartz) are occasionally exposed, with a medium overall-sorting deviation and imperfect roundness. The heavy minerals include detrital zircon, tourmaline, etc. Most of the detrital quartz is single-crystal quartz, which is subangular, and a small amount is melted irregularly with obvious intragranular fragmentation (Figure 3g), accounting for 
$62 \% \sim 70 \%$ of the detrital content. A large bulk of the feldspathic monomicts are subangular, while a small fraction is subcircular, accounting for $8 \% \sim 20 \%$ of the debris content. Among these kinds of monomicts, the potassium feldspar is predominantly microcline feldspar, which has undergone slight clayification. The above optical characteristics indirectly indicate that most of the quartz and feldspar monomicts are derived from intermediateacid volcanic rocks. Monomicts account for $10 \% \sim 20 \%$ of the debris content, which is dominated by volcanic rock debris, quartzite, and granite debris.

The sandstones of the Shimengou Formation $\left(\mathrm{J}_{2} \mathrm{~s}\right)$ are yellow-green; the ore-bearing lithology is mainly yellow-green and coarse sandstone (Figure $3 \mathrm{~h}, \mathrm{i}$ ), with an overall sandy composition (Figure $3 \mathrm{j}$ ) and massive structure. The monomicts are mainly composed of quartz, feldspar, and lithic clast, with particle sizes ranging from $0.25 \mathrm{~mm}$ to $0.53 \mathrm{~mm}$. The local micro-gravels (mostly single-crystal quartz and granite breccia) and cements are predominantly calcite and iron. The overall roundness of the rocks is poor, and the sorting is also poor. Most of the quartz debris is subangular, with corroded edges and obvious "exploding cracks" (Figure 3j,k), indicating that it is mostly derived from intermediateigneous acid rocks, accounting for $60 \% \sim 68 \%$ of the debris content. Polycrystalline quartz particles are less exposed. Lithic clast accounts for $20 \%$ 26\% of the monomicts, dominated by chert, granite debris, and volcanic rock debris (Figure 3j,1). The feldspar debris is dominated by perthite and microcline, with gridiron twin-crystals and obvious perthitic texture (Figure $3 \mathrm{k}, \mathrm{m}$ ). Plagioclase is rarely exposed, and the content of feldspar accounts for $8 \% \sim 14 \%$ of the monomicts. Epigenetic alterations, such as kaolinization, carbonization, and chloritization, have evolved locally in the rocks.

\subsection{Characteristics of Major Elements}

The major element data of Jurassic sandstones in the studied area are shown in Table 1. The $\mathrm{SiO}_{2}$ contents of sandstones of the Caishiling Formation $\left(\mathrm{J}_{3} \mathrm{c}\right)$ and Shimengou Formation $\left(\mathrm{J}_{2} \mathrm{~s}\right)$ range from $58.92 \%$ to $86.13 \%$ and from $59.82 \%$ to $89.41 \%$; the average contents are $73.54 \%$ and $73.50 \%$, respectively. The content of $\mathrm{Al}_{2} \mathrm{O}_{3}$ vary substantially from $3.08 \%$ to $14.05 \%$ and from $5.43 \%$ to $16.20 \%$, the average contents being $7.64 \%$ and $8.96 \%$, respectively; the content of $\mathrm{Fe}_{2} \mathrm{O}_{3}{ }^{\mathrm{T}}$ ranges from $0.91 \%$ to $4.84 \%$ and from $1.44 \%$ to $3.74 \%$, respectively; the content of $\mathrm{MgO}$ ranges from $0.08 \%$ to $1.57 \%$ and from $0.15 \%$ to $1.66 \%$, respectively; the content of $\mathrm{Na}_{2} \mathrm{O}$ ranges from $0.08 \%$ to $0.32 \%$ and from $0.10 \%$ to $1.08 \%$, respectively; the content of $\mathrm{K}_{2} \mathrm{O}$ ranges from $1.15 \%$ to $2.24 \%$ and from $1.73 \%$ to $4.00 \%$, respectively. Except for the fact that the content of $\mathrm{SiO}_{2}$ is generally higher than that of PAAS and UCC [28], the other contents are lower than their counterparts of PAAS and UCC, indicating that the samples contain more compositions of quartz and clay. Particular sandstone samples from the Caishiling and Shimengou Formations have a higher $\mathrm{CaO}$ content and loss on ignition (LOI), reflecting that the samples may contain a small amount of calcareous cement and carbonate rock monomicts.

\subsection{Characteristics of Trace Elements and Rare Earth Elements}

The data for trace elements and rare earth elements in sandstones are shown in Table 2. The average contents of $\mathrm{Rb}, \mathrm{Ba}$, and $\mathrm{Sr}$ are $106 \mathrm{ppm}, 493 \mathrm{ppm}$, and $80.9 \mathrm{ppm}$, respectively; apart from the content of $\mathrm{Rb}$ being slightly enriched in comparison with $\mathrm{UCC}$, while the others show characteristics of scarcity; mafic elements, like $\mathrm{Cr}$, Ni, and $\mathrm{Sc}$, are slightly deficient by contrast with UCC, reflecting that the sandstones in the studied area are rich in acidic components. The total amounts of rare earth elements in each group of sandstones are quite different, ranging from $55.22 \mathrm{ppm}$ to $251.30 \mathrm{ppm}$. The contents of LREE and HREE range from $48.98 \mathrm{ppm}$ to $225.80 \mathrm{ppm}$ and from $6.24 \mathrm{ppm}$ to $25.48 \mathrm{ppm}$, respectively. LREE/HREE ratio ranges between 7.56 and 12.56 (Table 2), indicating that LREE is enriched while HREE is depleted, and the LREE/HREE fractionation is obvious. The chondritenormalized REE patterns show a significant HREE depletion, with a moderately negative Eu anomaly $(\delta \mathrm{Eu}=0.45 \sim 0.73$, mean 0.61 ; Figure $4 \mathrm{a})$, and the REE partition curves of each sample are parallel to each other, showing that the contents of rare earth elements vary 
synchronously. The normalized REE partition curve of the North American shales shows a nearly horizontal distribution (Figure $4 \mathrm{~b}$ ), which indicates that the REE composition characteristics are similar to those of the North American shales and that the clastic rocks in the area stem from the continental upper crust.

Table 1. Major element analysis results of Jurassic sandstones in the Yuqia Area ( $\left.\mathrm{w}_{\mathrm{B}} / \%\right)$.

\begin{tabular}{|c|c|c|c|c|c|c|c|c|c|c|c|c|}
\hline $\begin{array}{c}\text { Sample } \\
\text { No. }\end{array}$ & $\mathrm{SiO}_{2}$ & $\mathrm{TiO}_{2}$ & $\mathrm{Al}_{2} \mathrm{O}_{3}$ & $\mathrm{Fe}_{2} \mathrm{O}_{3}^{\mathrm{T}}$ & $\mathrm{MnO}$ & $\mathrm{MgO}$ & $\mathrm{CaO}$ & $\mathrm{Na}_{2} \mathrm{O}$ & $\mathrm{K}_{2} \mathrm{O}$ & $\mathrm{P}_{2} \mathrm{O}_{5}$ & LOI & Total \\
\hline \multicolumn{13}{|c|}{ Caishiling Formation $\left(\mathrm{J}_{3} \mathrm{c}\right)$} \\
\hline YK2-1 & 69.38 & 0.67 & 13.21 & 2.20 & 0.06 & 1.15 & 3.66 & 0.19 & 2.24 & 0.09 & 6.79 & 99.64 \\
\hline YK3-2 & 58.92 & 0.21 & 4.58 & 0.91 & 0.33 & 0.38 & 17.40 & 0.08 & 1.15 & 0.06 & 15.23 & 99.25 \\
\hline YK2-3 & 59.15 & 0.87 & 14.05 & 4.84 & 0.14 & 1.57 & 6.51 & 0.32 & 1.89 & 0.15 & 8.68 & 98.17 \\
\hline YK1-4 & 74.04 & 0.10 & 5.65 & 1.61 & 0.20 & 0.28 & 8.16 & 0.25 & 2.08 & 0.02 & 7.39 & 99.78 \\
\hline YK1-5 & 86.13 & 0.30 & 6.46 & 2.45 & 0.15 & 0.45 & 0.13 & 0.11 & 1.85 & 0.04 & 1.87 & 99.94 \\
\hline YK2-6 & 83.87 & 0.29 & 7.13 & 3.47 & 0.04 & 0.59 & 0.14 & 0.11 & 2.03 & 0.04 & 2.07 & 99.78 \\
\hline YK1-7 & 83.53 & 0.23 & 6.92 & 3.89 & 0.05 & 0.35 & 0.12 & 0.29 & 2.24 & 0.02 & 1.25 & 98.89 \\
\hline YK1-8 & 73.26 & 0.04 & 3.08 & 0.93 & 0.12 & 0.08 & 11.10 & 0.16 & 1.43 & 0.01 & 9.66 & 99.87 \\
\hline \multicolumn{13}{|c|}{ Shimenggou Formation $\left(\mathrm{J}_{2} \mathrm{~s}\right)$} \\
\hline YK2-9 & 80.89 & 0.32 & 8.45 & 1.51 & 0.03 & 0.73 & 0.51 & 0.35 & 4.00 & 0.01 & 2.92 & 99.72 \\
\hline YK3-10 & 62.55 & 0.46 & 11.47 & 3.74 & 0.06 & 1.34 & 7.35 & 0.24 & 3.54 & 0.04 & 8.68 & 99.47 \\
\hline YK1-11 & 73.99 & 0.23 & 7.52 & 1.65 & 0.03 & 1.66 & 5.21 & 0.18 & 2.98 & 0.02 & 6.61 & 100.08 \\
\hline YK1-12 & 69.62 & 0.40 & 9.91 & 2.65 & 0.05 & 1.55 & 5.24 & 0.42 & 3.42 & 0.03 & 6.66 & 99.95 \\
\hline YK1-13 & 89.41 & 0.11 & 5.71 & 1.44 & 0.01 & 0.15 & 0.04 & 0.10 & 2.25 & 0.01 & 1.30 & 100.53 \\
\hline YK2-14 & 70.71 & 0.85 & 16.20 & 2.95 & 0.15 & 0.79 & 0.20 & 0.17 & 2.53 & 0.04 & 4.93 & 99.52 \\
\hline YK3-15 & 59.82 & 0.39 & 9.13 & 3.43 & 0.05 & 1.42 & 10.25 & 1.08 & 1.73 & 0.12 & 11.23 & 98.65 \\
\hline YK1-16 & 75.98 & 0.31 & 6.86 & 2.02 & 0.10 & 0.39 & 4.62 & 0.83 & 2.04 & 0.02 & 7.06 & 100.23 \\
\hline Yk2-17 & 78.54 & 0.15 & 5.43 & 1.70 & 0.11 & 0.16 & 4.97 & 0.54 & 2.10 & 0.02 & 6.28 & 100.00 \\
\hline PAAS & 62.80 & 1.00 & 18.90 & 7.22 & 0.11 & 2.20 & 1.30 & 1.20 & 3.70 & 0.16 & - & - \\
\hline UCC & 66.60 & 0.64 & 15.40 & 5.04 & 0.10 & 2.48 & 3.59 & 3.27 & 2.80 & 0.15 & - & - \\
\hline
\end{tabular}

Note: PAAS and UCC data from Taylor and McLennan [28].
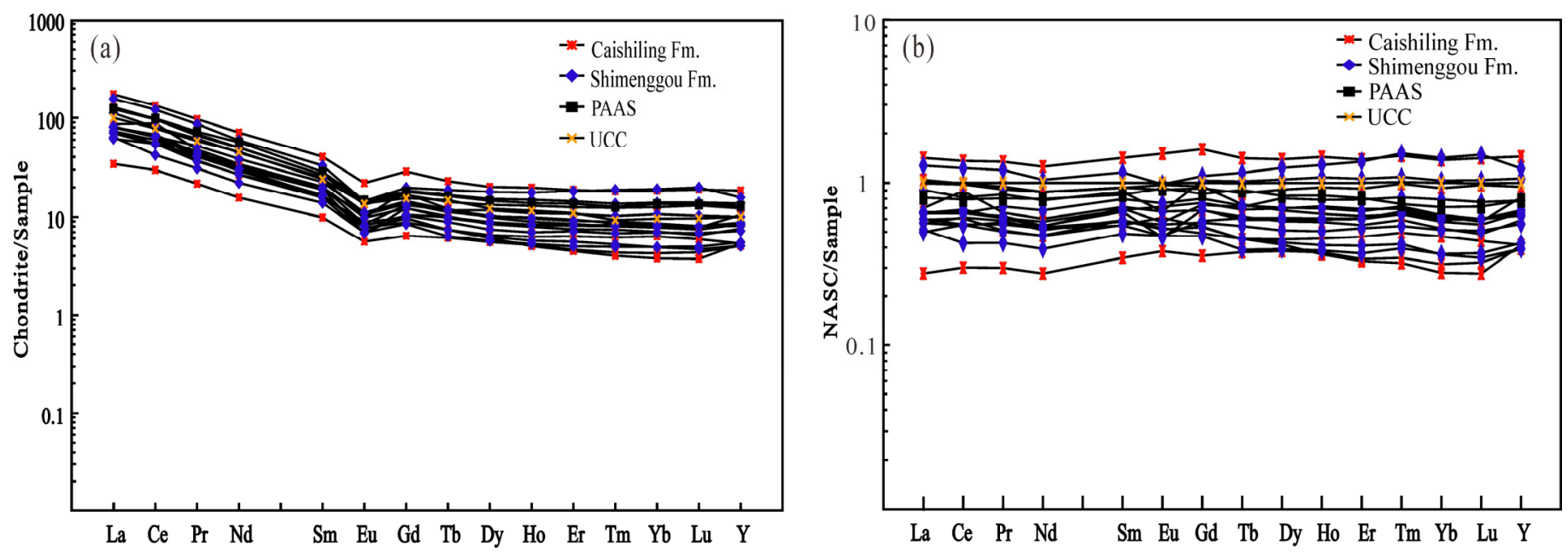

Figure 4. (a) The standard REE curve of chondrites for Jurassic sandstones at the Yuqia uranium occurrences (data from Sun and McDonough [29]), and (b) normalized curves for North American shales (NASC; data from Haskin and Paster [30]). 
Table 2. Trace element analysis results of Jurassic sandstones in the Yuqia Area ( $\left.w_{\mathrm{B}} / \%\right)$

\begin{tabular}{|c|c|c|c|c|c|c|c|c|c|c|c|c|c|c|c|c|c|}
\hline \multirow{2}{*}{ Sample } & \multicolumn{8}{|c|}{ Caishiling Formation $\left(\mathrm{J}_{3} \mathrm{c}\right)$} & \multicolumn{9}{|c|}{ Shimenggou Formation $\left(J_{2} s\right)$} \\
\hline & YK2-1 & YK3-2 & YK2-3 & YK1-4 & YK1-5 & YK2-6 & YK1-7 & YK1-8 & YK2-9 & YK3-10 & YK1-11 & YK1-12 & YK1-13 & YK2-14 & YK3-15 & YK1-16 & YK2-17 \\
\hline Sc & 10.10 & 3.00 & 12.80 & 1.70 & 4.10 & 4.80 & 3.20 & 1.80 & 3.10 & 6.70 & 2.80 & 6.00 & 1.60 & 13.40 & 7.50 & 3.90 & 2.30 \\
\hline $\mathrm{Cr}$ & 61.00 & 17.00 & 83.00 & 12.00 & 37.00 & 22.00 & 17.00 & 9.00 & 25.00 & 31.00 & 18.00 & 35.00 & 13.00 & 53.00 & 85.00 & 20.00 & 17.00 \\
\hline $\mathrm{Rb}$ & 116.00 & 44.80 & 109.00 & 76.10 & 72.80 & 82.40 & 88.50 & 50.80 & 194.00 & 194.00 & 147.00 & 167.50 & 82.70 & 141.50 & 80.80 & 79.90 & 74.20 \\
\hline $\mathrm{Ba}$ & 435.00 & 539.00 & 301.00 & 417.00 & 451.00 & 590.00 & 412.00 & 288.00 & 689.00 & 591.00 & 603.00 & 591.00 & 430.00 & 709.00 & 530.00 & 407.00 & 394.00 \\
\hline Th & 15.90 & 5.29 & 18.00 & 4.91 & 7.37 & 8.97 & 6.76 & 3.01 & 13.00 & 19.25 & 11.45 & 12.75 & 5.88 & 20.30 & 6.70 & 8.10 & 5.11 \\
\hline $\mathrm{U}$ & 2.83 & 1.00 & 3.78 & 0.86 & 2.49 & 2.21 & 2.64 & 0.72 & 1.37 & 2.22 & 1.03 & 1.57 & 1.59 & 5.84 & 1.66 & 1.99 & 1.34 \\
\hline $\mathrm{Ta}$ & 1.09 & 0.34 & 1.19 & 0.32 & 0.46 & 0.46 & 0.43 & 0.15 & 0.73 & 1.13 & 0.52 & 0.73 & 0.31 & 1.33 & 0.44 & 0.53 & 0.35 \\
\hline $\mathrm{Sr}$ & 72.7 & 77.3 & 114.5 & 137.5 & 51.7 & 51.1 & 43.6 & 83.9 & 59.8 & 88 & 69.1 & 96.8 & 42.2 & 72.4 & 167.5 & 86.7 & 59.9 \\
\hline Hf & 6.10 & 2.00 & 9.30 & 1.70 & 3.40 & 3.30 & 2.80 & 1.40 & 3.00 & 7.30 & 3.80 & 4.90 & 2.50 & 10.00 & 4.20 & 4.80 & 2.50 \\
\hline $\mathrm{La}$ & 39.80 & 25.20 & 54.00 & 22.70 & 26.70 & 38.00 & 21.50 & 10.60 & 24.80 & 34.60 & 22.90 & 24.90 & 19.00 & 48.60 & 25.30 & 21.70 & 19.70 \\
\hline $\mathrm{Ce}$ & 78.80 & 52.30 & 108.00 & 48.20 & 70.90 & 77.90 & 48.80 & 24.00 & 51.70 & 64.90 & 44.20 & 54.50 & 44.00 & 97.80 & 52.00 & 43.5 & 33.9 \\
\hline $\operatorname{Pr}$ & 8.37 & 5.36 & 11.85 & 4.51 & 5.80 & 8.07 & 5.17 & 2.65 & 5.52 & 7.51 & 4.91 & 5.35 & 4.43 & 10.55 & 6.32 & 5.06 & 3.77 \\
\hline $\mathrm{Nd}$ & 29.90 & 19.60 & 42.50 & 16.00 & 20.40 & 29.70 & 17.40 & 9.40 & 18.50 & 26.50 & 17.80 & 18.40 & 16.10 & 35.40 & 23.00 & 18.10 & 13.30 \\
\hline $\mathrm{Sm}$ & 5.20 & 3.78 & 7.85 & 3.06 & 3.95 & 5.18 & 3.27 & 1.92 & 3.69 & 4.89 & 3.04 & 3.86 & 3.27 & 6.41 & 4.41 & 3.21 & 2.70 \\
\hline $\mathrm{Eu}$ & 0.98 & 0.77 & 1.62 & 0.66 & 0.72 & 1.05 & 0.57 & 0.41 & 0.5 & 0.72 & 0.51 & 0.62 & 0.56 & 1.06 & 0.81 & 0.60 & 0.51 \\
\hline $\mathrm{Gd}$ & 4.32 & 3.51 & 7.44 & 2.51 & 3.16 & 4.44 & 2.28 & 1.66 & 3.18 & 4.81 & 2.72 & 3.41 & 2.49 & 5.12 & 3.73 & 2.66 & 2.19 \\
\hline $\mathrm{Tb}$ & 0.67 & 0.53 & 1.09 & 0.35 & 0.48 & 0.57 & 0.35 & 0.29 & 0.46 & 0.79 & 0.47 & 0.55 & 0.35 & 0.89 & 0.56 & 0.42 & 0.30 \\
\hline Dy & 4.26 & 3.26 & 6.49 & 1.95 & 2.72 & 3.17 & 2.10 & 1.78 & 2.77 & 4.90 & 2.85 & 3.76 & 2.01 & 5.77 & 3.29 & 2.39 & 1.83 \\
\hline Ho & 0.93 & 0.71 & 1.42 & 0.36 & 0.57 & 0.64 & 0.45 & 0.37 & 0.59 & 1.07 & 0.60 & 0.78 & 0.41 & 1.27 & 0.69 & 0.50 & 0.38 \\
\hline $\mathrm{Tm}$ & 0.40 & 0.28 & 0.59 & 0.13 & 0.24 & 0.26 & 0.20 & 0.14 & 0.26 & 0.44 & 0.27 & 0.33 & 0.17 & 0.61 & 0.29 & 0.22 & 0.16 \\
\hline $\mathrm{Yb}$ & 2.62 & 1.75 & 3.87 & 0.79 & 1.48 & 1.63 & 1.32 & 0.89 & 1.67 & 2.91 & 1.72 & 2.23 & 1.02 & 3.99 & 1.79 & 1.45 & 1.03 \\
\hline $\mathrm{Lu}$ & 0.42 & 0.25 & 0.61 & 0.12 & 0.21 & 0.24 & 0.19 & 0.14 & 0.26 & 0.45 & 0.26 & 0.33 & 0.15 & 0.64 & 0.26 & 0.22 & 0.16 \\
\hline $\mathrm{Y}$ & 25.60 & 22.00 & 38.90 & 11.20 & 15.90 & 17.70 & 11.20 & 10.60 & 17.00 & 28.70 & 17.60 & 21.00 & 10.60 & 33.00 & 18.30 & 15.10 & 11.50 \\
\hline$\Sigma$ REE & 179.30 & 119.27 & 251.30 & 102.28 & 138.9 & 172.63 & 104.93 & 55.22 & 115.61 & 157.51 & 103.97 & 121.27 & 95.13 & 221.94 & 124.36 & 101.53 & 80.98 \\
\hline LREE & 163.05 & 107.01 & 225.80 & 95.13 & 128.47 & 159.90 & 96.71 & 48.98 & 104.71 & 139.12 & 93.36 & 107.63 & 87.36 & 199.82 & 111.84 & 92.17 & 73.88 \\
\hline HREE & 16.25 & 12.26 & 25.45 & 7.15 & 10.43 & 12.730 & 8.22 & 6.24 & 10.90 & 18.39 & 10.61 & 13.64 & 7.77 & 22.12 & 12.52 & 9.36 & 7.10 \\
\hline LREE/HREE & 10.03 & 8.73 & 8.87 & 13.30 & 12.32 & 12.56 & 11.77 & 7.85 & 9.61 & 7.56 & 8.80 & 7.89 & 11.24 & 9.03 & 8.93 & 9.85 & 10.41 \\
\hline $\mathrm{La} / \mathrm{Yb}$ & 15.19 & 14.4 & 13.95 & 28.73 & 18.04 & 23.31 & 16.29 & 11.91 & 14.85 & 11.89 & 13.31 & 11.17 & 18.63 & 12.18 & 14.13 & 14.97 & 19.13 \\
\hline $\mathrm{La}_{\mathrm{N}} / \mathrm{Yb}_{\mathrm{N}}$ & 10.27 & 9.73 & 9.43 & 19.42 & 12.19 & 15.75 & 11.01 & 8.05 & 10.04 & 8.03 & 9.00 & 7.55 & 12.59 & 8.23 & 9.55 & 10.11 & 12.92 \\
\hline$\delta \mathrm{Eu}$ & 0.63 & 0.65 & 0.65 & 0.73 & 0.62 & 0.67 & 0.64 & 0.70 & 0.45 & 0.45 & 0.54 & 0.52 & 0.60 & 0.57 & 0.61 & 0.63 & 0.64 \\
\hline
\end{tabular}

Note: content unit is ppm. 


\subsection{Mineral Chemistry of Uranium Minerals}

The chemical composition analysis of uranium minerals in ore-bearing sandstones by EPMA is shown in Table 3. Uranium minerals are dominated by coffinite and pitchblende, which are the substantive uranium minerals first reported in the region. Their chemical compositions are quite similar, with relatively rich contents of $\mathrm{U}, \mathrm{Si}$, and $\mathrm{Ca}$, and lower levels of $\mathrm{Th}, \mathrm{Mg}, \mathrm{Mn}, \mathrm{Ni}, \mathrm{V}, \mathrm{Pb}$, etc. The particle sizes of coffinite are concentrated within the range of $1 \mu \mathrm{m}$ to $4 \mu \mathrm{m}$. The contents of $\mathrm{UO}_{2}, \mathrm{SiO}_{2}, \mathrm{CaO}$, and $\mathrm{FeO}$ in coffinite range from $59.97 \%$ to $80.76 \%, 6.24 \%$ to $17.65 \%, 1.13 \%$ to $3.94 \%$, and $0.38 \%$ to $2.59 \%$, respectively. The content of $\mathrm{Y}_{2} \mathrm{O}_{3}$ ranges between $0.35 \%$ and $6.04 \%$. In addition, uranite contains trace amounts of $\mathrm{Na}_{2} \mathrm{O}, \mathrm{TiO}_{2}, \mathrm{MgO}, \mathrm{Al}_{2} \mathrm{O}_{3}$, etc. The particle sizes of pitchblende are concentrated within the range of $1 \mu \mathrm{m}$ to $5 \mu \mathrm{m}$. The content of $\mathrm{UO}_{2}$ in pitchblende ranges between $79.57 \%$ and $84.82 \%, \mathrm{SiO}_{2}$ content between $1.30 \%$ and $4.49 \%$, $\mathrm{ThO}_{2}$ content between $3.49 \%$ and $4.52 \%, \mathrm{CaO}$ content between $0.57 \%$ and $3.90 \%$, and $\mathrm{PbO}$ content between $1.17 \%$ and $1.63 \%$; the pitchblende also contains trace amounts of $\mathrm{Na}_{2} \mathrm{O}, \mathrm{Y}_{2} \mathrm{O}_{3}, \mathrm{MgO}$, and $\mathrm{Al}_{2} \mathrm{O}_{3}$. It is noteworthy that the individual coffinite particles under test are found to contain unequal amounts of $\mathrm{Y}_{2} \mathrm{O}_{3}, \mathrm{P}_{2} \mathrm{O}_{5}, \mathrm{FeO}$, and $\mathrm{SO}_{3}$, probably due to their small diameters and the close paragenesis to xenotimes and pyrites, so trace components have been introduced during the test.

Table 3. Results of the electron microprobe analysis of uranium minerals in the Yuqia uranium occurrences $(\%)$.

\begin{tabular}{|c|c|c|c|c|c|c|c|c|c|}
\hline Sample No. & U-2-1 & U-2-3 & U-2-4 & U-2-6 & U-2-7 & U-2-9 & U-2-11 & U-2-12 & U-2-13 \\
\hline Mineral & \multicolumn{5}{|c|}{ Coffinite } & \multicolumn{4}{|c|}{ Pitchblende } \\
\hline $\mathrm{SiO}_{2}$ & 9.35 & 9.27 & 6.24 & 10.77 & 17.65 & 1.68 & 1.30 & 4.49 & 1.70 \\
\hline $\mathrm{ThO}_{2}$ & - & - & - & - & - & 4.52 & - & - & 3.49 \\
\hline $\mathrm{TiO}_{2}$ & 0.28 & 0.79 & 0.21 & 0.18 & 0.26 & - & - & 0.15 & - \\
\hline $\mathrm{UO}_{2}$ & 60.73 & 74.66 & 80.76 & 66.33 & 59.97 & 79.57 & 84.82 & 80.68 & 80.41 \\
\hline $\mathrm{FeO}$ & 2.59 & 0.99 & 0.91 & 1.45 & 0.38 & 0.25 & 0.32 & 1.01 & 0.61 \\
\hline $\mathrm{Na}_{2} \mathrm{O}$ & 0.6 & 0.33 & 0.34 & 0.51 & 1.03 & 0.84 & 0.13 & 0.51 & 0.23 \\
\hline $\mathrm{MgO}$ & 0.06 & 0.05 & - & 0.12 & 0.10 & 0.09 & 0.10 & 0.08 & 0.08 \\
\hline $\mathrm{MnO}$ & - & 0.24 & 0.17 & 0.08 & - & - & - & 0.15 & 0.10 \\
\hline $\mathrm{Y}_{2} \mathrm{O}_{3}$ & 6.04 & 0.41 & 0.35 & 4.54 & 5.66 & 0.97 & 0.12 & 0.98 & 0.42 \\
\hline $\mathrm{Al}_{2} \mathrm{O}_{3}$ & 0.64 & 0.15 & 0.42 & 0.08 & 0.65 & 0.08 & 0.02 & 0.41 & 0.13 \\
\hline $\mathrm{NiO}$ & - & - & - & 0.12 & - & 0.18 & 0.11 & - & - \\
\hline $\mathrm{K}_{2} \mathrm{O}$ & 0.21 & 0.14 & 0.18 & 0.19 & 0.17 & 0.16 & 0.17 & 0.26 & 0.27 \\
\hline $\mathrm{V}_{2} \mathrm{O}_{3}$ & - & - & 0.09 & - & 0.12 & - & - & - & - \\
\hline $\mathrm{CaO}$ & 3.94 & 1.13 & 1.29 & 2.35 & 2.36 & 0.57 & 3.90 & 2.66 & 2.22 \\
\hline $\mathrm{SO}_{3}$ & 3.41 & 2.13 & 0.05 & 1.16 & 0.03 & 0.09 & - & 0.19 & 0.14 \\
\hline $\mathrm{PbO}$ & - & - & - & - & 0.05 & 1.63 & - & - & 1.17 \\
\hline $\mathrm{P}_{2} \mathrm{O}_{5}$ & 2.38 & 0.19 & 0.20 & 4.28 & 1.63 & 0.06 & 1.46 & 0.96 & - \\
\hline Total & 90.23 & 90.48 & 91.21 & 92.16 & 90.06 & 90.69 & 92.45 & 92.53 & 91.97 \\
\hline
\end{tabular}

Note: “-" represents values below the detection limit.

\section{Discussion}

\subsection{Characteristics of Uranium Minerals}

Two kinds of uranium minerals, coffinite and pitchblende, have been focused on in this study. There are obvious differences in their composition of major elements and forms of occurrence. Electron probe backscattering (BSE) images of uranium minerals have shown that coffinite and pitchblende exist in different forms and various occurrences. By morphological size, distribution location, and mineral paragenetic relationship, they can be classified into three types of occurrence and forms:

(1) Here, coffinite and pitchblende are anhedral, irregularly granular, stellate or colloidal, and are distributed at the edge of a strawberry-like pyrite (Figure 5a). Local coffinite and strawberry-like pyrite are closely cemented together (Figure $5 b$ ), with obvious symbiosis. Electron probe analysis has shown that coffinite contains a small amount 
of $\mathrm{FeO}(2.59 \%)$ and $\mathrm{SO}_{3}(3.41 \%)$, with a relatively low content of $\mathrm{UO}_{2}(60.73 \%)$. Pitchblende presents a higher $\mathrm{UO}_{2}$ (mean $81.37 \%$ ) and less $\mathrm{FeO}$ and $\mathrm{SO}_{3}$. This indicates that coffinite is closely related to the strawberry-like pyrite in the formation process, which provides sufficient reductant for the uranium mineralization process.

(2) Here, coffinite and pitchblende are anhedral crystals with irregular granular and colloidal shapes, distributed at the edge of heavy mineral xenotimes, cements, and quartz particles (Figure 5a,c). Some particles are closely symbiotic with xenotimes, and individual coffinite particles are linear and are surrounded by quartz particles, which leads to an illusory encapsulation phenomenon. Coffinite contains rich $\mathrm{SiO}_{2}$ $(9.35 \% \sim 17.65 \%)$ and $\mathrm{Y}_{2} \mathrm{O}_{3}(4.54 \% \sim 6.04 \%)$, with an average $\mathrm{UO}_{2}$ content of $62.34 \%$. Pitchblende has a relative content of $\mathrm{UO}_{2}$, ranging from $79.57 \%$ to $84.82 \%$, and contains a small amount of $\mathrm{CaO}, \mathrm{ThO}_{2}$, and $\mathrm{PbO}$. The common feature of these forms of coffinite and pitchblende is that they both contain a certain amount of $\mathrm{Y}_{2} \mathrm{O}_{3}$, which may be closely related to the symbiotic mineral xenotimes.

(3) Here, coffinite, both irregular granular and stellate, fills in quartz fissures or corrosion pits (Figure $5 \mathrm{~d}$ ). The content of $\mathrm{UO}_{2}$ in this kind of coffinite is generally richer than in the above two kinds of coffinite. The content of $\mathrm{UO}_{2}$ ranges from $74.66 \%$ to $80.76 \%$, and the corresponding content of $\mathrm{SiO}_{2}$ ranges from $6.24 \%$ to $9.27 \%$. Combined with the backscattering images, there is no obvious symbiosis of pyrite or phosphite surrounding the coffinite, so the contents of $\mathrm{Y}_{2} \mathrm{O}_{3}, \mathrm{FeO}$, and $\mathrm{SO}_{3}$ in this kind of coffinite are demonstrably lower than in the previous two forms of coffinite.
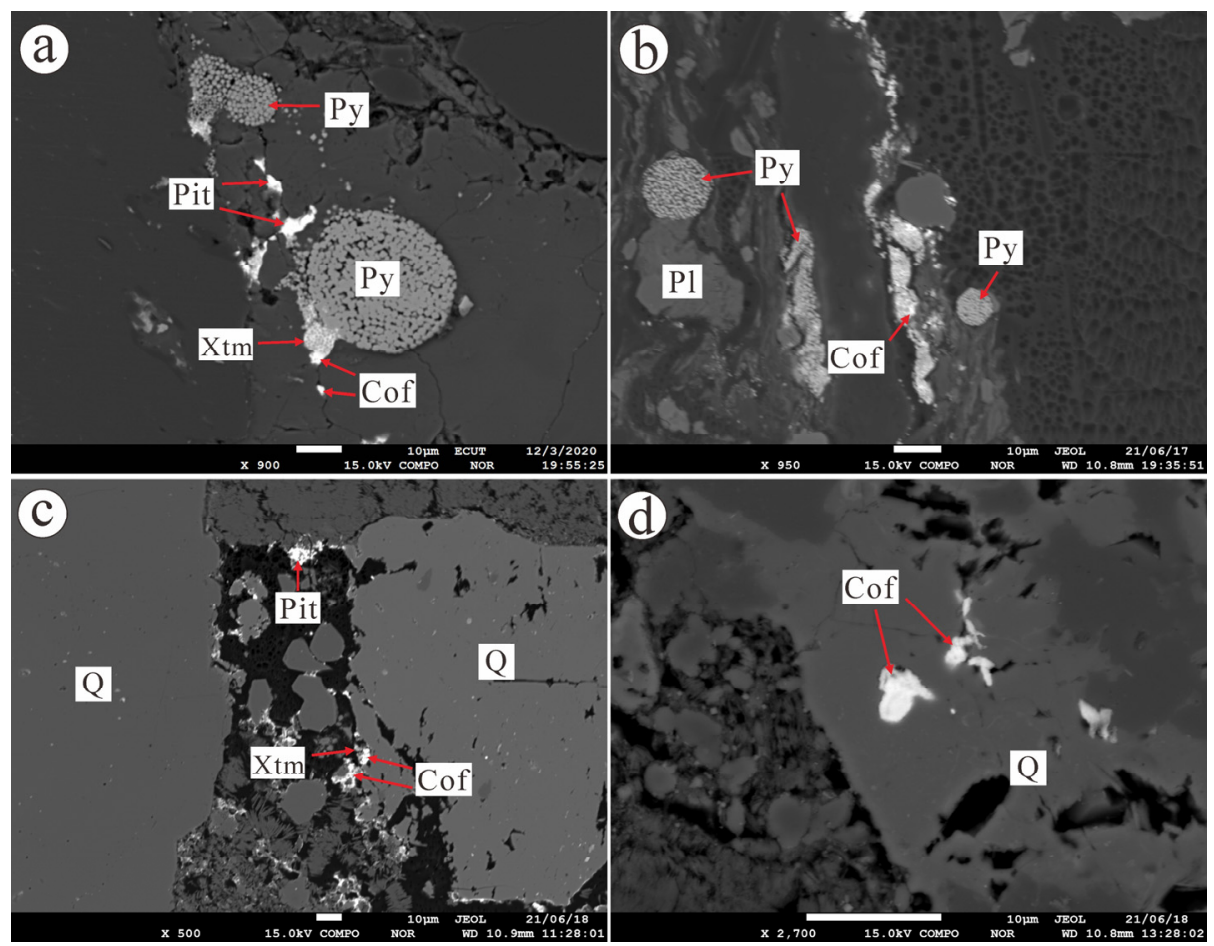

Figure 5. Microscopic characteristics of uranium minerals in the Yuqia uranium occurrences. $(\mathbf{a}, \mathbf{b})$ Coffinite and pitchblende, distributed in irregular granular and gelatinous forms at the edges of strawberry pyrites and xenotimes, or cemented with strawberry pyrites; (c) pitchblende and coffinite distributed in irregular granular and starlike shape at the edge of quartz; (d) the coffinite distributed in quartz fissures or corrosion pits in the form of irregular grains. Abbreviations: Q, quartz; Pit, pitchblende; Cof, coffinite; Py, pyrite; Xtm, xenotime.

\subsection{Tectonic Background of the Source Region}

The relative contents of different clasts in clastic rocks are the most compelling direct evidence that objectively reflects the tectonic background of sandstone source areas. Based on the characteristics of clastic components in sandstones, the tectonic settings of clastic rock 
provenances are divided by foreign experts into continental plates (craton interior, basement uplift, and transitional continental area), island arcs (incised island arc, non-incised island arc, and transitional arc), and recycled orogenic belts (quartz recycled, transitional recycled, and lithic recycled) $[19,31]$. Table 4 shows the statistical results of the detrital compositions of Jurassic sandstone samples in the studied area. While sandstone samples in the Qt-F-L and Qm-F-Lt diagrams fall basically within the ranges of the recycled orogenic belt and the quartz recycled area (Figure 6a,b), sandstone samples in the Qp-Lv-Ls diagram fall within the ranges of the arc orogenic belt area and the transitional area between the arc orogenic belt and the subduction complex belt (Figure 6c).

Table 4. The statistics of the detrital grains of Jurassic sandstone samples in the Yuqia area.

\begin{tabular}{|c|c|c|c|c|c|c|c|c|c|c|c|}
\hline Sample & Lithologic Description & Qm & Qp & Qt & $\mathbf{F}$ & $\mathbf{L v}$ & Ls & Lm & $\mathbf{L}$ & $\mathbf{L t}$ & Total \\
\hline \multicolumn{12}{|c|}{ Caishiling Formation $\left(\mathrm{J}_{3} \mathrm{c}\right)$} \\
\hline YK2-1 & Fine sandstone & 208 & 22 & 230 & 30 & 21 & 10 & 9 & 40 & 62 & 300 \\
\hline YK3-2 & Medium sandstone & 216 & 18 & 234 & 18 & 24 & 15 & 9 & 48 & 66 & 300 \\
\hline YK2-3 & Fine sandstone & 184 & 26 & 210 & 48 & 26 & 7 & 13 & 46 & 72 & 304 \\
\hline YK1-4 & Medium sandstone & 180 & 42 & 222 & 30 & 33 & 6 & 9 & 48 & 90 & 300 \\
\hline YK1-5 & Medium sandstone & 185 & 31 & 216 & 37 & 37 & 9 & 9 & 55 & 86 & 308 \\
\hline YK2-6 & Medium sandstone & 120 & 27 & 147 & 99 & 30 & 6 & 18 & 54 & 81 & 300 \\
\hline YK1-7 & Medium sandstone & 186 & 6 & 192 & 37 & 43 & 13 & 25 & 81 & 87 & 310 \\
\hline YK1-8 & Coarse sandstone & 180 & 18 & 198 & 30 & 36 & 18 & 18 & 72 & 90 & 300 \\
\hline \multicolumn{12}{|c|}{ Shimenggou Formation $\left(\mathrm{J}_{2} \mathrm{~s}\right)$} \\
\hline YK2-9 & Coarse sandstone & 173 & 46 & 219 & 53 & 24 & 3 & 4 & 31 & 99 & 303 \\
\hline YK3-10 & Fine sandstone & 154 & 42 & 196 & 48 & 30 & 14 & 13 & 57 & 99 & 301 \\
\hline YK1-11 & Coarse sandstone & 165 & 30 & 195 & 44 & 52 & 6 & 5 & 63 & 74 & 302 \\
\hline YK1-12 & Coarse sandstone & 174 & 29 & 203 & 58 & 28 & 5 & 8 & 41 & 70 & 302 \\
\hline YK1-13 & Medium sandstone & 172 & 24 & 196 & 30 & 51 & 15 & 9 & 75 & 99 & 301 \\
\hline YK2-14 & Medium sandstone & 182 & 30 & 212 & 24 & 43 & 9 & 15 & 67 & 97 & 303 \\
\hline $\begin{array}{l}\text { YK3- } \\
15(a)\end{array}$ & Medium sandstone & 162 & 12 & 174 & 42 & 63 & 6 & 15 & 84 & 96 & 300 \\
\hline $\begin{array}{l}\text { YK3- } \\
\text { 15(b) }\end{array}$ & Medium sandstone & 180 & 15 & 195 & 39 & 30 & 12 & 24 & 66 & 81 & 300 \\
\hline YK1-16 & Medium sandstone & 186 & 18 & 204 & 24 & 42 & 15 & 15 & 72 & 90 & 300 \\
\hline YK2-17 & Coarse sandstone & 165 & 15 & 180 & 42 & 45 & 12 & 21 & 78 & 93 & 300 \\
\hline
\end{tabular}

Note: Qm, monocrystalline quartz; Qp, polycrystalline quartz; Qt, total quartz; F, feldspar; Lv, lithic volcanic clasts; Ls, lithic sedimentary and metasedimentary clasts; Lm, lithic metamorphic clasts; L, lithic clasts; $\mathrm{Qt}=\mathrm{Qm}+\mathrm{Qp} ; \mathrm{L}=\mathrm{Lv}+\mathrm{Ls}+\mathrm{Lm} ; \mathrm{Lt}=\mathrm{L}+\mathrm{Qp}$.

The element geochemistry of clastic rocks can be used to identify the paleotectonic environment of sedimentary basins. For example, the inactive trace elements $\mathrm{Zr}$, $\mathrm{Hf}$, Ti, Sc, Th, and La could imply information relevant to diagenetic material sources. The nature of the source area is closely related to the tectonism to which the adjacent sedimentary basins have been subjected. For example, the source area of the sandstones formed in the fore-arc basin at the active continental margin is dominated by a magmatic arc [31]. Therefore, the geochemical characteristics of various elements can be used to effectively identify the source rock type and tectonic background [32-34]. The values of the $\delta \mathrm{Eu}$, $\Sigma R E E$, and $\mathrm{La}_{\mathrm{N}} / \mathrm{Yb}_{\mathrm{N}}$ ratios of the Jurassic sandstone samples in the studied area indicate that the tectonic setting of the provenance is close to the active continental margin, while the $\mathrm{Sc} / \mathrm{Cr}, \mathrm{Zr} / \mathrm{Th}$ and $\mathrm{Rb} / \mathrm{Sr}$ ratios are close to those of the passive continental margin (Table 2). According to the Th-Sc-Zr/10 and La-Th-Sc diagrams proposed by Bhatia et al. (1986) [19], the sandstone samples in the studied area basically fall within the boundary range between the active continental margin and passive continental margin (Figure $7 \mathrm{a}, \mathrm{b}$ ); in the $\mathrm{La} / \mathrm{Sc}-\mathrm{Ti} / \mathrm{Zr}$ diagram, the sandstone samples all fall near the environment of the active continental margin or passive continental margin (Figure 7c). Because the clastic components and geochemical characteristics of clastic rocks are inherited from the tectonic background of the source area, the complex tectonic background identified through the 
preceding geochemical characteristics analysis cannot represent the tectonic environment where the clastic rocks were formed, but it reveals the tectonic environment where the clastic source rocks were formed [34-36]. To a certain extent, this also reflects the complexity of the tectonic background where the source area rocks were formed.

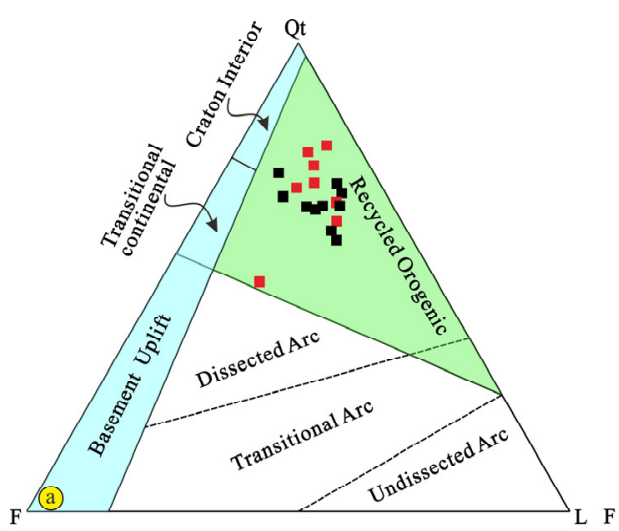

- Caishiling Fm.

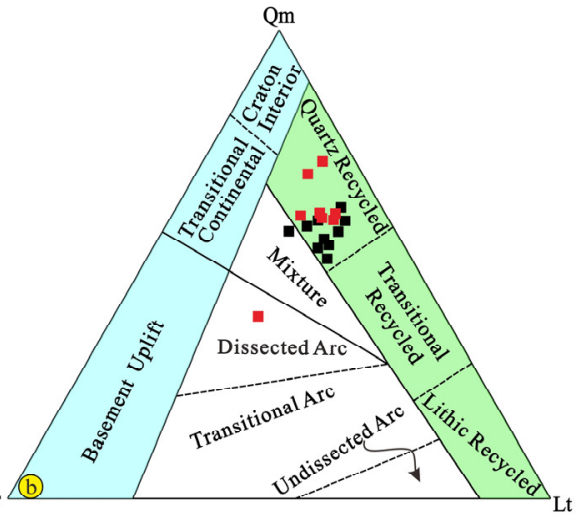

F: feldspar I.: lithic clas Lv: lithic volcanic clasts

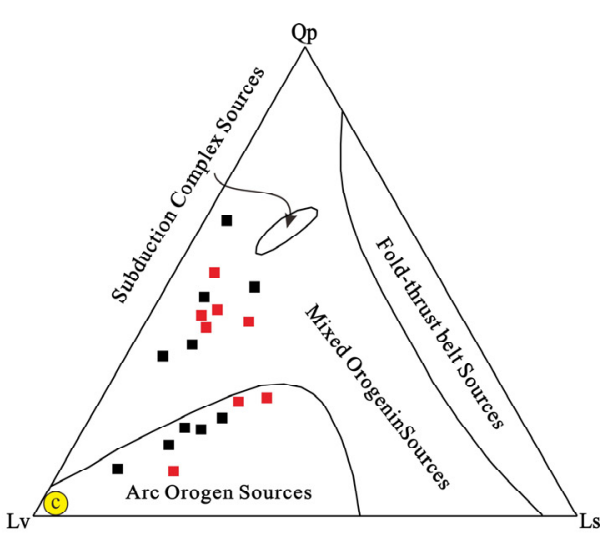

Qm: monocrystalline quartz Ls: lithic sedimentary and metasedimentary clasts

Figure 6. Dickinson diagram of Jurassic sandstones in Yuqia uranium occurrences (modified after Dickinson and Suczek [18]). (a) Qt-F-L diagram, (b) Qm-F-L diagram, (c) Qp-Lv-Ls diagram.

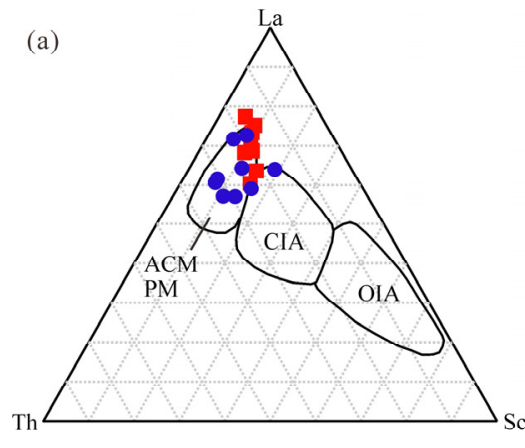

OIA: Oceanic island arc
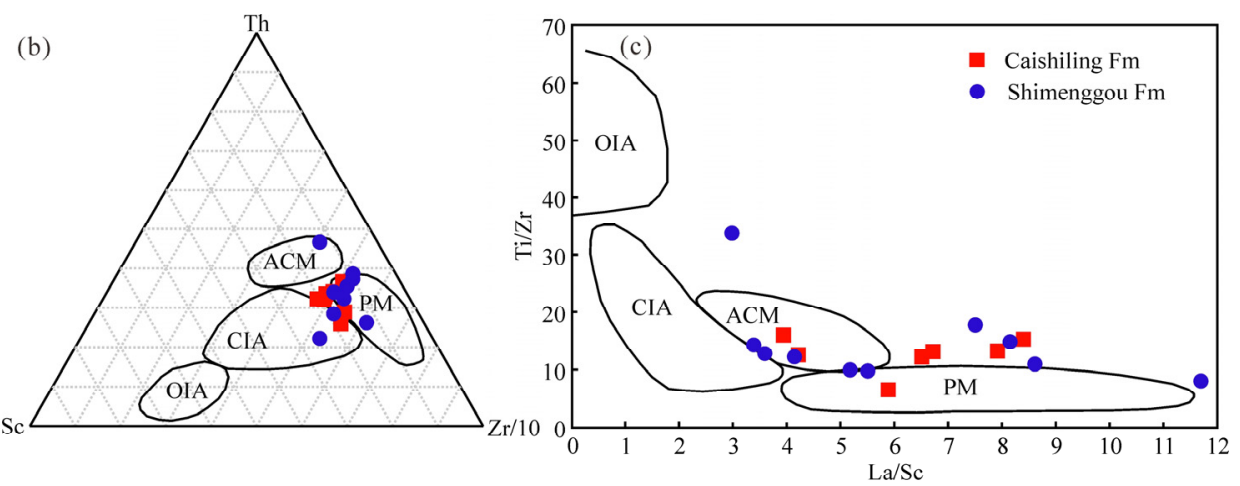

PM: Passive continental margin

Figure 7. A trace element discrimination map of tectonic environment of Jurassic sandstones in Yuqia uranium occurrences (modified after [32]). (a) La-Th-Sc diagram, (b) Th-Sc-Zr/10 diagram, (c) $\mathrm{La} / \mathrm{Sc}-\mathrm{Ti} / \mathrm{Zr}$ diagram.

\subsection{Provenance Analysis}

The major and trace elements in clastic rocks have a certain relationship to their provenances. For example, the contents and ratios of trace elements, such as Th, Sc, and Co, are of considerable indicative significance to the provenance area of clastic rocks. Compared with basic rocks, acidic rocks are enriched in La and Th, while being depleted in Sc, $\mathrm{Cr}$, and $\mathrm{Co}$; thus, the $\mathrm{La} / \mathrm{Sc}$, Th/Sc, and $\mathrm{Cr} / \mathrm{Th}$ ratios can effectively identify the rock types of clastic source areas. At the same time, the dilution effect of quartz and other substances can be avoided $[28,37]$. The $\mathrm{La} / \mathrm{Sc}$ ratio of Jurassic sandstone in the studied area ranges from 6.50 to 7.12 , and the Th/Sc ratio ranges from 1.89 to 2.63 , both obviously higher than those of UCC, while the $\mathrm{Cr} / \mathrm{Th}$ ratio ranges from 3.38 to 3.46 (Table 5); thus, the source rocks of clastic forms are more likely acidic igneous rocks. According to the La/Th-Hf diagram [38], most of the samples fall in the acidic source region and in its vicinity (Figure 8a). In the Th-Sc diagram [39], except for one sample from the Shimengou Formation, falling within the neutral source area, all the other samples fall within the acidic source area (Figure $8 b$ ), indicating that acidic igneous components dominate over minor intermediate components in the sandstone source area. Therefore, it is preliminarily considered that 
the Jurassic sandstone source rocks in the studied area are mostly acidic, with only an iota of minor intermediate components. Their compositions are similar to those of granites (granodiorites) and quartz diorites.

Table 5. Ratio-discriminant table of trace elements of Jurassic sandstones in the Yuqia uranium ore fields.

\begin{tabular}{ccccccc}
\hline Parameter & $\begin{array}{c}\text { Caishiling } \\
\text { Formation }\end{array}$ & $\begin{array}{c}\text { Shimenggou } \\
\text { Formation }\end{array}$ & $\begin{array}{c}\text { Mafic } \\
\text { Provenance }\end{array}$ & $\begin{array}{c}\text { Felsic } \\
\text { Provenance }\end{array}$ & Upper Crust & Lower Crust \\
\hline La/Sc & 7.12 & 6.50 & $0.40 \sim 1.10$ & $2.50 \sim 16.00$ & 2.70 & 0.30 \\
Th/Sc & 1.89 & 2.63 & $0.04 \sim 0.05$ & $0.83 \sim 20.00$ & 1.00 & 0.03 \\
Cr/Th & 3.38 & 3.46 & $22.00 \sim 100.00$ & $0.50 \sim 7.70$ & 3.30 & 222.00 \\
\hline Data & \multicolumn{2}{c}{$[37]$} & & {$[28]$} \\
Sources & This article & & & \\
\hline
\end{tabular}

Note: The Jurassic sandstone data shows the average value of the samples in each layer.
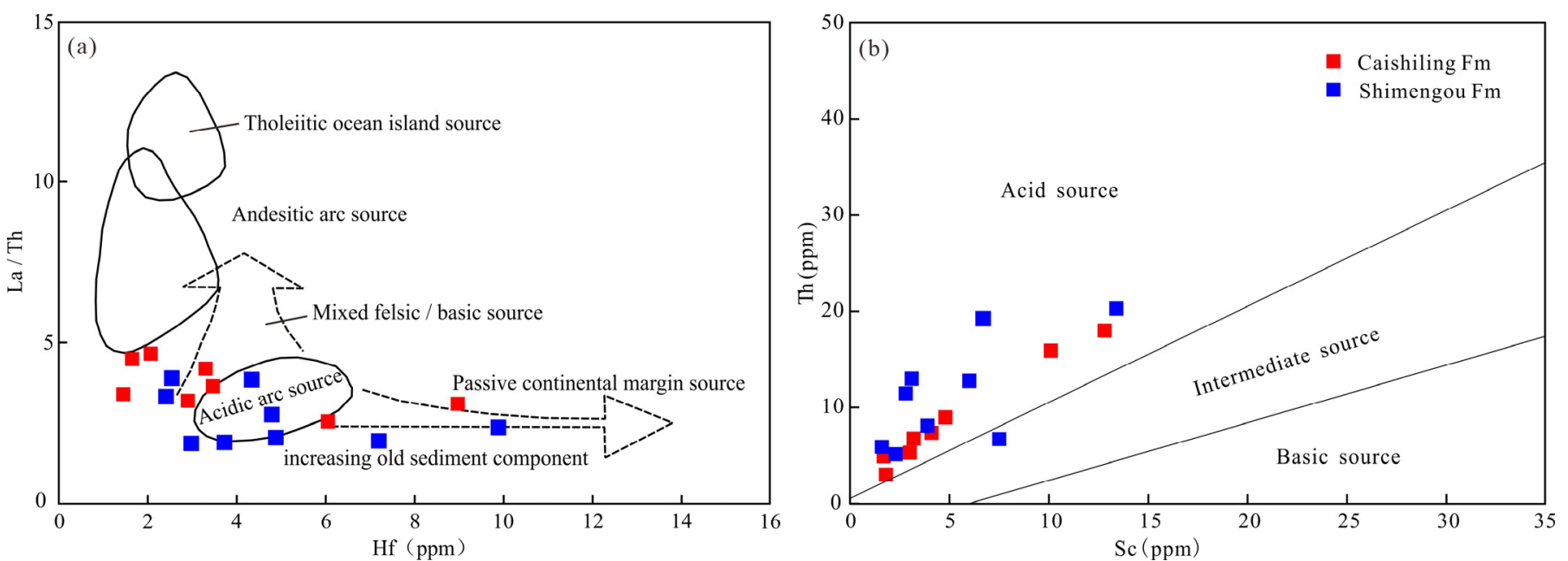

Figure 8. Provenance discrimination diagrams of (a) La/Th-Hf and (b) Th-Sc for sandstones in the studied area (modified after [38,39]).

The northern margin of the Qaidam Basin is an important Caledonian orogenic belt, mainly comprising Saishiteng Mountain, Aolao Mountain, Lvliang Mountain, and Xitieshan Mountain. The outcropping lithology features high-pressure and ultra-high-pressure metamorphic rocks, island arc volcanic rocks, and Paleozoic granites [40-45]. Paleozoic granites (including granodiorites, quartz diorites, monzonites, etc.) are distributed mainly in the Saishiteng Mountain, Aolao Mountain, Qaidam Mountain, and Tuanyu Mountain areas in the eastern part of the northern margin of the Qaidam Basin, with ages ranging from 469 to $360 \mathrm{Ma}$ [46-55] and from 271 to $215 \mathrm{Ma}$, respectively [48,56-59]. They have the properties of an island arc or an active continental margin [48,49,56-59]. Qian et al., (2018) [3] determined that the Th/U ratios of detrital zircons in Jurassic sandstones in the northern margin of Qaidam Basin range from 0.38 to 0.78 and from 0.37 to 1.85, respectively. Typical magmatic rhythmic belts have developed, mainly composed of magmatic zircons. The ages of detrital zircon U-Pb are concentrated mainly within 484 to $358 \mathrm{Ma}$ for $\mathrm{n}=49$ and 278 to $214 \mathrm{Ma}$ for $\mathrm{n}=53$, respectively, close to the ages of the granites exposed in the northern margin of the Qaidam Basin. Combined with the elemental geochemical characteristics of sandstones in the studied area, and previous evidence of detrital zircon chronology, it is suggested that the source rocks of the detrital rocks in the studied area may be dominated by Indosinian granites and Paleozoic granites, exposed in the northern margin of the Qaidam tectonic belt. In addition, plenty of the granite debris (Figure $3 \mathrm{j}, 1, \mathrm{~m}$ ) is distributed in the 
Jurassic sandstones of the studied area, which provides further supplementary evidence for the above inference.

\subsection{Inspiration from Uranium Mineralization}

Previous studies have shown that the wall rocks that host sandstone-type uranium deposits can serve as an important source of ore-forming materials. The contribution of the wall rocks to uranium mineralization is governed directly by the active uranium contents of the rocks in the source region, whereby those wall rocks with higher uranium concentrations are favorable for preliminary enrichment [60,61]. A large number of Indosinian and Early Paleozoic granites are exposed in Saishiteng Mountain, Aolao Mountain, Dakendaban Mountain in the northeast, and Lvliang Mountain in the south of the vicinity of the studied area, and the $U$ content of these granites is generally high (3.0 7.8 ppm). The Th content ranges within 12.5 and $64.1 \mathrm{ppm}[21,22,41,48,49,58]$ and this is widely recognized as a uranium-rich formation. According to research by certain experts, the average Th/U ratio of rocks in mainland China is 4.2 ; where the $\mathrm{Th} / \mathrm{U}$ ratio of rocks is greater than 4.2 , it can be considered that uranium is obviously deficient there [60]. The Th/ $\mathrm{U}$ ratio of the granite body of the Yuqia uranium deposit in the pitting source area ranges from 4.17 to 8.22 [22,58], indicating that there has been a massive uranium emigration from the uranium-rich granite body in the source area, which abounds in uranium sources for the Yuqia area. Secondly, the uranium content in the sand body of the Shimenggou Formation in the studied area is relatively high (1.6-5.1 ppm) [22,58], which indicates that during the weathering and denudation of the source rocks, the uranium-bearing rock was transported to the Yuqia depression zone, along with the surface water and other accumulation. The sandstone contains a large amount of carbonaceous organic matter, thin coal seams, pyrites, and other reductants $[61,62]$. The sandstones in the early stage of burial always existed in a reducing environment so that the uranium-bearing debris was preserved, which has further led to the pre-enrichment of uranium in Shimengou Formation sandstones.

In nature, uranium occurrences mainly exist in three forms: substantive uranium minerals (uraninite, pitchblende, etc.), isomorphism (uranium-bearing accessory minerals, such as zircon, monazite, etc.), and dispersed adsorption state (often adsorbed by coal seams, clay minerals, etc.) [63]. Uranium migrates in the hexavalent state $\left(\mathrm{U}^{6+}\right)$ under oxidizing conditions, in the forms of uranyl carbonate complexes, uranyl phosphate complexes, or uranyl fluoride complexes; while under reducing conditions, it precipitates toward the tetravalent state $\left(\mathrm{U}^{4+}\right)$ to form substantive uranium minerals, such as pitchblende, uraninite, and coffinite [64-67]. During the Jurassic-Cretaceous period, numerous coal- and hydrocarbon-bearing strata were deposited in the northern continental basins, forming a typical red-black rock serial structure, which represented the main metallogenic horizon of sandstone-type uranium deposits in the north. The conjugated black rock series and red rock series in Mesozoic continental basins were formed through the transformation of an ancient sedimentary environment from a reducing to an oxidizing state; that is, the red layers formed under oxidizing conditions provided a "field" for the dissolution of uranium deposits by supergene fluids, while the black rock series provided a "barrier" for the precipitation of uranium minerals. It can be seen that sandstone-type uranium deposits in northern continental basins are closely associated with the "red-black rock series" in time and space [68-70]. The Yuqia area is an important region for the exploitation of coal, oil, and gas resources in the northern margin of the Qaidam Basin, and most of the oil and gas resources occur in the Middle Jurassic ore-bearing strata. With the direct upward movement of the reverse faults that developed in the area, reducing gases such as $\mathrm{CH}_{4}$ and $\mathrm{H}_{2} \mathrm{~S}$ were generated. In addition, a large number of pyrites and coal-bearing organic matters that were distributed over the area served as reducing media, which provided the necessary reducing agents for uranium mineralization in the area. The uranium-rich oxygen-containing water from the source area, with uranium-containing groundwater and atmospheric precipitation, forms a uranium-rich fluid that directly penetrates into the ore-forming sand bodies vertically, and the uranium-rich fluids continuously produce free 
$\left[\mathrm{UO}_{2}\right]^{2+}$. When the concentration of $\left[\mathrm{UO}_{2}\right]^{2+}$ reaches saturation, along with the reductant (such as reducing gas $\mathrm{CH}_{4}, \mathrm{H}_{2} \mathrm{~S}$, coal line and sulfide-pyrite, etc.) in the Yuka area, $\left[\mathrm{UO}_{2}\right]^{2+}$ undergoes a redox reaction, and $\mathrm{U}^{6+}$ is reduced into $\mathrm{U}^{4+}$ in the form of the independent uranium minerals, coffinite and pitchblende.

\section{Conclusions}

It is reported herein for the first time that coffinite and pitchblende are the main independent uranium minerals in the region, which mainly occur in strawberry pyrite, xenotime and its margins or concave pits of quartz.

Based on the detrital components and elemental geochemistry of sandstones, and detrital zircon $\mathrm{U}-\mathrm{Pb}$ geochronology, it is concluded that the source area rocks of Jurassic sandstones in the Yuqia uranium mines mainly formed in the tectonic backgrounds of active continental margins. The sediments are mainly sourced from Indosinian granites and Paleozoic granitoids, exposed in the tectonic belt in the northern margin of the Qaidam Basin.

By comparing the $\mathrm{U}$ and Th contents and Th/U ratios of the Indosinian and Early Paleozoic granites in the source area, it has been found that the uranium preconcentration in the sandstone-type uranium from the ore-bearing target stratum is mainly attributable to the source supply of uranium-rich granites in the source area. Finally, it appears that the uranium oxygen-bearing water from the source area infiltrated into the uranium-rich sand bodies of the target stratum and precipitated uranium through a redox reaction.

Author Contributions: Conceptualization, G.H. (Guangwen Huang) and D.W.; methodology, P.F.; software, Z.M.; validation, G.H. (Guangnan Huang) and W.X.; formal analysis, Z.M.; investigation, P.F.; resources, G.H. (Guangnan Huang); data curation, D.W. and G.H. (Guangwen Huang); writing — original draft preparation, G.H. (Guangwen Huang) and D.W.; writing-review and editing, G.H. (Guangwen Huang) and D.W.; visualization, G.H. (Guangwen Huang) and G.H. (Guangnan Huang); supervision, W.X. and Z.M.; project administration, D.W.; funding acquisition, D.W. and G.H. (Guangwen Huang). All authors have read and agreed to the published version of the manuscript.

Funding: This study was financially supported by the Open Fund Project from the State Key Laboratory of Nuclear Resources and Environment of the East China University of Technology (2020NRE03), The Key Laboratory of the Northern Qinghai-Tibet Plateau Geological Processes and Mineral Resources Fund Project (grant number 2019-KY-04), The Postgraduate Innovation Fund Project of Jiangxi Province, China (grant number YC2021-B161).

Institutional Review Board Statement: Not applicable.

Informed Consent Statement: Not applicable.

Data Availability Statement: Data is contained within the article.

Acknowledgments: We greatly appreciate the help of Zhibo Zhang and Minghui Yin during daily discussion work.

Conflicts of Interest: The authors declare no conflict of interest.

\section{References}

1. Chen, X.H.; Dang, Y.Q.; Yin, A.; Wang, L.Q.; Jiang, W.M.; Jiang, R.B.; Zhou, S.P.; Liu, M.D.; Ye, B.Y.; Zhang, M.; et al. BasinMountain Coupling and Tectonic Evolution of Qaidam Basin and Its Adjacent Orogenic Belts; Geological Publishing House: Beijing, China, 2010; pp. 1-365. (In Chinese)

2. Shao, L.Y.; Li, M.; Li, Y.H.; Zhang, Y.P.; Lu, J.; Zhang, W.L.; Tian, Z.; Wen, H.J. Geological characteristics and controlling factors of shale gas in the Jurassic of the northern Qaidam Basin. Earth Sci. Front. 2014, 21, 311-322. (In Chinese, with English abstract)

3. Qian, T.; Wang, Z.X.; Liu, Y.Q.; Liu, S.F.; Gao, W.L.; Li, W.P.; Hu, J.J.; Li, L.L. Provenance analysis of the Jurassic northern Qaidam Basin: Stratigraphic succession and LA-ICP-MS geochronology. Sci. Sin. Terrae 2018, 48, 224-242, (In Chinese, with English abstract).

4. Yin, A.; Rumelhart, P.E.; Butler, R.; Cowgill, E.; Harrison, T.; Foster, D.; Ingersoll, R. Tectonic history of the Altyn Tagh fault system in northern Tibet inferred from Cenozoic sedimentation. GSA Bull. 2002, 114, 1257-1295. [CrossRef]

5. Yin, A.; Dang, Y.Q.; Zhang, M.; Chen, X.H.; Mcrivette, M.W. Cenozoic tectonic evolution of the Qaidam basin and its surrounding regions (Part 3): Structural geology, sedimentation, and regional tectonic reconstruction. GSA Bull. 2008, 120, 813-846. [CrossRef] 
6. Weltje, G.J.; Eynatten, H. Quantitative provenance analysis of sediments: Review and outlook. Sediment. Geol. 2004, 171, 1-11. [CrossRef]

7. Li, Z.; Peng, S.T. U-Pb geochronological records and provenance system analysis of the Mesozoic-Cenozoic sandstone detrital zircons in the northern and southern piedmonts of Tianshan, Northwest China: Responses to intracontinental basin-range evolution. Acta Petrol. Sin. 2013, 29, 739-755, (In Chinese, with English abstract).

8. Yu, R.A.; Si, Q.H.; Wang, S.B.; Zhu, Q.; Liu, X.X.; Wang, H.B.; Tang, Y.X. Geochemical Characteristics and Detrital Zircon U-Pb Ages of the Zhiluo Formation in the Shicaocun Area of the Western Ordos Basin and Implication for its Tectonic Setting and Provenance. Geotect. Metall. 2020, 44, 754-771. (In Chinese, with English abstract)

9. Yin, A.; Manning, C.E.; Lovera, O.; Menold, C.A.; Chen, X.H.; Gehrels, G.E. Early Paleozoic tectonic and thermomechanical evolution of ultrahigh-pressure (UHP) metamorphic rocks in the northern Tibetan Plateau, northwest China. Int. Geol. Rev. 2007, 49, 681-716. [CrossRef]

10. Lu, H.J.; Ye, J.C.; Guo, L.C.; Pan, J.W.; Xiong, S.F.; Li, H.B. Towards a clarification of the provenance of Cenozoic sediments in the northern Qaidam Basin. Lithosphere 2018, 11, 252-272. [CrossRef]

11. Bush, M.; Saylor, J.; Horton, B.; Nie, J. Growth of the Qaidam Basin during Cenozoic exhumation in the northern Tibetan Plateau: Inferences from depositional patterns and multiproxy detrital provenance signatures. Lithosphere 2016, 8, 58-82. [CrossRef]

12. Ji, J.L.; Zhang, K.X.; Clift, P.D.; Zhuang, G.S.; Song, B.W.; Ke, X.; Xu, Y.D. High-resolution magnetostratigraphic study of the Paleogene-Neogene strata in the northern Qaidam Basin: Implications for the growth of the northeastern Tibetan Plateau. Gondwana Res. 2017, 46, 141-155. [CrossRef]

13. Wang, W.T.; Zheng, W.J.; Zhang, P.Z.; Li, Q.; Kirby, E.; Yuan, D.Y.; Zheng, D.W.; Liu, C.C.; Wang, Z.C.; Zhang, H.P.; et al. Expansion of the Tibetan Plateau during the Neogene. Nat. Commun. 2017, 8, 15887. [CrossRef] [PubMed]

14. Jian, X.; Guan, P.; Zhang, W.; Liang, H.; Feng, F.; Fu, L. Late Cretaceous to early Eocene deformation in the northern Tibetan Plateau: Detrital apatite fission track evidence from the northern Qaidam Basin. Gondwana Res. 2018, 60, 94-104. [CrossRef]

15. Sun, G.Q.; Wang, Y.T.; Yun, J.; Pan, S.L.; Zhang, S.C.; Zhang, M.F. Provenance and tectonic setting of Paleogene sandstone in the center of the northern Qaidam basin, China. J. Nat. Gas Geosci. 2020, 5, 273-284. [CrossRef]

16. Liu, K.; Wang, W.T.; Zhao, X.D.; Pang, J.Z.; Yu, J.X. Provenance identification for the Honggou section of the Qaidam basin in the northeastern margin of the Tibetan Plateau and its tectonic significance. Acta Geol. Sin. 2020, 94, 716-728. (In Chinese, with English abstract)

17. Zeng, X.; Lin, T.; Wang, W.; Yan, Z.D.; Hao, C.G.; Bian, Y.Y.; Wang, J. Detrital zircon dating of LA-ICP-MS in the Upper Jurassic and indicative significance of the Qaidam basin. Nut. Gas Geosci. 2019, 30, 662-672, (In Chinese, with English abstract).

18. Dickinson, W.R.; Suczek, C.A. Plate tectonics and sandstone compositions. Assoc. Petrol. Geol. Bull. 1979, 63, $2164-2182$.

19. Bhatia, M.R.; Crook, K.A.W. Trace element characteristics of graywacks and tectonic discrimination of sedimentary basins. Contrib. Miner. Petrol. 1986, 92, 181-193. [CrossRef]

20. Yan, M.Q.; Zhang, D.H.; Marten, J.H.; Wei, J.H.; Li, H.; Li, G.M.; Huang, X.K.; Zhang, X.M.; Zhao, S.Q. Mineralogical and isotopic characterization of graphite deposits in the western part of the North Qaidam Orogen and East Kunlun Orogen, northeast Tibetan Plateau, China. Ore Geol. Rev. 2020, 126, 103778. [CrossRef]

21. Lian, K.; Zhao, X.Q.; Wang, J.B.; Song, Y. Condition and Potential of Sandstone-type Uranium Meatallization in Yuqia Area, Northern Qaidam Basin. Uranium Geol. 2020, 36, 145-155, (In Chinese, with English abstract).

22. Liu, L.; Feng, W.; Chen, Q. Uranium forming conditions and exploration prospect in the Northeast margin of Qaidamu. J. East China Instit. Technol. Nat. Sci. 2013, 36, 249-254, (In Chinese, with English abstract).

23. Yang, Y.T.; Zhang, B.M.; Li, W.; Qu, H. Study of Jurassic stratigraphic Sequence and sedimentary facies in North of Qaidam basin. Earth Sci. Front. 2000, 7, 145-151, (In Chinese, with English abstract).

24. Chen, Z.Y.; Xiao, A.C.; Zhou, S.P.; He, G.Y. The main control factor for Jurassic distribution in Qaidam Basin. Earth Sci. Front. 2005, 12, 149-155, (In Chinese, with English abstract).

25. Chen, F.; Hegner, E.; Todt, W. Zircon ages and Nd isotopic and chemical compositions of orthogneisses from the Black Forest, Germany: Evidence for a Cambrian magmatic arc. Int. J. Earth Sci. 2000, 88, 791-802. [CrossRef]

26. Li, J.; Zhong, J.W.; Yu, Y.; Huang, X.L. Insights on magmatism and mineralization from micas in the Xihuashan granite, Jiangxi Province, South China. Geochimica 2013, 42, 393-404, (In Chinese, with English abstract).

27. Zhou, J.X. Quantitative Analysis of Silicate Minerals by Electron Probe Method; Standards Press of China: Beijing, China, 2002; pp. 1-8. (In Chinese)

28. Taylor, S.R.; McLennan, S.M. The Continental Crust: Its Composition and Evolution; Blackwell Scientific Publications: Oxford, UK, 1985; pp. 1-312.

29. Sun, S.S.; McDonough, W.F. Chemical and isotopic systematics of oceanic basalts: Implications for mantle composition and processes. Magmatism in the Ocean Basalts. Geol. Soc. Publ. 1989, 42, 313-345. [CrossRef]

30. Haskin, L.A.; Paster, T.P. Geochemistry and mineralogy of the rare earths. In Handbook on the Physics and Chemistry of Rare Earths; Elsevier: Oxford, UK, 1979; Volume 3, pp. 1-80.

31. Dickinson, W.R. Compositions of sandstones in Circum-Pacific subduction complexes and fore-arc basins. AAPG Bull. 1982, 66, 121-137. 
32. Wu, R.C.; Gu, X.X.; Zhang, Y.M.; He, G.; Kang, J.Z.; Yu, F.C.; Feng, L.Q.; Xu, J.C. The sedimentary geochemical records about the tectonic evolution of the East Kunlun Orogenic Belt from early paleozoic to early Mesozoic. Geoscience 2017, 31, 716-733. (In Chinese, with English abstract)

33. Roser, B.P.; Korsch, R.J. Determination of tectonic setting of sandstone-mudstone suites using $\mathrm{SiO}_{2}$ content and $\mathrm{K}_{2} \mathrm{O} / \mathrm{Na}_{2} \mathrm{O}$ ratio. J. Geol. 1986, 94, 635-650. [CrossRef]

34. Zhao, D.J.; Wang, X.Q. Geochemical characteristics of the Middle Triassic fine-grained clastic sedimentary rocks in Youjiang Basin and its implications for provenance and tectonic setting. Geotect. Metall. 2019, 44, 311-324. (In Chinese, with English abstract)

35. Zhang, X.; Nie, F.J.; Xia, F.; Zhang, C.Y.; Feng, Z.B.; Ullah, R.; Zhang, P.F. Provenance constraints on the Xishanyao Formation, southern Yili Basin, northwest China: Evidence from petrology, geochemistry, and detrital zircon U-Pb geochronology. Can. J. Earth Sci. 2018, 55, 1020-1035. [CrossRef]

36. Li, S.Y.; Li, R.W.; Meng, Q.R.; Wang, D.X. Radiometric dating of sediments derived from metamorphic rocks of the Dabie Orogenic Belt in the Jurassic and Early Cretaceous. Prog. Nat. Sci. 2006, 16, 194-202.

37. Cullers, R. The controls on the major and trace element variation of shales, siltstones and sandstones of Pennsylvanian-Permian age from uplifted continental blocks in Colorado to platform sediment in Kansas, USA. Geochim. Cosmochim. Acta 1994, 58, 4955-4972. [CrossRef]

38. Floyd, P.A.; Leveridge, B.E. Tectonic environment of the Devonian Gramscatho basin, south Cornwall: Framework mode and geochemical evidence from turbiditic sandstones. J. Geol. Soc. 1987, 144, 531-542. [CrossRef]

39. Mclennan, S.M.; Hemming, S.; Mcdaniel, D.K. Geochemical approaches to sedimentation, provenance, and tectonics. Geol. Soc. Am. 1993, 284, 21-40.

40. Song, S.G.; Su, L.; Li, X.H.; Niu, Y.L.; Zhang, L.F. Grenville-age orogenesis in the Qaidam-Qilian block: The link between South China and Tarim. Precambrian Res. 2012, 220, 9-22. [CrossRef]

41. Song, S.G.; Niu, Y.L.; Su, L.; Zhang, C.; Zhang, L.F. Continental orogenesis from ocean subduction, continent collision/subduction, to orogen collapse, and orogen recycling: The example of the North Qaidam UHPM belt, NW China. Earth-Sci. Rev. 2014, 129, 59-84. [CrossRef]

42. Shi, R.D.; Yang, J.S.; Wu, C.L.; Iizuka, T.; Hirata, T.; Tsuyoshi, I.; Takafumi, H. Island arc volcanic rocks in the north Qaidam UHP belt, northern Tibet plateau: Evidence for ocean-continent subduction preceding continent-continent subduction. J. Asian Earth Sci. 2006, 28, 151-159.

43. Song, S.G.; Zhang, L.F.; Niu, Y.L.; Su, L.; Song, B.; Liu, D.Y. Evolution from oceanic subduction to continental collision: A case study from the Northern Tibetan Plateau based on geochemical and geochronological data. J. Petrol. 2006, 47, 435-455. [CrossRef]

44. Song, S.G.; Su, L.; Niu, Y.L.; Zhang, L.F.; Zhang, G.B. Petrological and geochemical constraints on the origin of garnet peridotite in the North Qaidam ultrahigh-pressure metamorphic belt, Northwestern China. Lithos 2007, 96, 243-265. [CrossRef]

45. Xiong, Q.; Zheng, J.; Griffin, W.L.; O'Reilly, S.Y.; Pearson, N.J. Decoupling of U-Pb and Lu-Hf isotopes and trace elements in zircon from the UHP North Qaidam orogen, NE Tibet (China): Tracing the deep subduction of continental blocks. Lithos 2012, 155, 125-145. [CrossRef]

46. Wu, C.L.; Yang, J.S.; Xu, Z.Q.; Wooden, J.L.; Ireland, T.; Li, H.B.; Shi, R.D.; Meng, F.C.; Chen, S.N.; Persng, H.; et al. Granitic Magmatism on the early Paleozoic UHP belt of Northern Qaidam, NW China. Acta Geol. Sin. 2004, 78, 658-674. (In Chinese, with English abstract)

47. Wu, C.L.; Gao, Y.H.; Wu, S.P.; Chen, Q.L.; Wooden, J.L.; Mazadab, F.K.; Mattinson, C. Zircon SHRIMP U-Pb dating of Granites from the Da Qaidam area in the north margin of Qaidam basin, NW China. Acta Petrol. Sin. 2007, 23, 1861-1875. (In Chinese, with English abstract)

48. Wu, C.L.; Gao, Y.H.; Wu, S.P.; Chen, Q.L.; Wooden, J.L.; Mazadab, F.K.; Mattinson, C. Zircon SHRIMP U-Pb dating of granites and geochemical characteristics in the Western part of Northern Qaidam. Sci. China Earth Sci. 2008, 38, 930-949. (In Chinese, with English abstract)

49. Wu, C.L.; Gao, Y.H.; Li, Z.L.; Lei, M.; Qin, H.P.; Li, M.Z.; Liu, C.H.; Frost, R.B.; Robinson, P.T.; Wooden, J.L. Zircon SHRIMP U-Pb dating of granites from Dulan and the chronological framework of the North Qaidam UHP belt, NW China. Sci. China Earth Sci. 2014, 44, 2142-2159. (In Chinese, with English abstract) [CrossRef]

50. Lu, X.X.; Sun, Y.G.; Zhang, X.T.; Xiao, Q.H.; Wang, X.X.; Wei, X.D.; Gu, D.M. The SHRIMP age of Tatalin Rapakivi granite at the North Margin of Qaidam basin. Acta Geol. Sin. 2007, 81, 626-634. (In Chinese, with English abstract)

51. Meng, F.C.; Zhang, J.X. Contemporaneous of early Palaeozoic granite and high temperature metamorphism, North Qaidam Mountains, western China. Acta Petrol. Sin. 2008, 24, 1585-1594. (In Chinese, with English abstract)

52. Zhou, B.; Zheng, Y.Y.; Xu, R.K.; Wang, Y.K.; Zhang, X.P.; Wu, L. LA-ICP-MS zircon U-Pb dating and Hf isotope geochemical characteristics of Qaidamshan intrusive body. Geol. Bull. China 2013, 32, 1027-1034. (In Chinese, with English abstract)

53. Wang, M.; Song, S.; Niu, Y.L.; Su, L. Post-collisional magmatism: Consequences of UHPM terrane exhumation and orogen collapse, N. Qaidam UHPM belt, NW China. Lithos 2014, 210, 181-198. [CrossRef]

54. Peng, Y.; Ma, Y.S.; Liu, C.L.; Li, Z.X.; Sun, J.P.; Shao, P.C. Geological characteristics and tectonic significance of the Indosinian granodiorites from the Zongwulong tectonic belt in North Qaidam. Earth Sci. Front. 2016, 23, $206-221$. (In Chinese, with English abstract) 
55. Song, S.G.; Niu, Y.L.; Su, L.; Wei, C.J.; Zhang, L.F. Adakitic (tonalitic-trondhjemitic) magmas resulting from eclogite decompression and dehydration melting during exhumation in response to continental collision. Geochim. Cosmochim. Acta 2014, $130,42-62$. [CrossRef]

56. Zhang, T.; Zhang, D.H.; Yang, B. SHRIMP zircon U-Pb dating of Gangcha intrusions in Qinghai and its geological significance. Acta Petrol. Sin. 2014, 30, 2739-2748. (In Chinese, with English abstract)

57. Dong, Z.C.; Gu, P.Y.; Chen, R.M.; Cha, X.F.; Zhang, H.D. Geochronology, Geochemistry, and Hf isotope of Yanchangbeishan adamellite of Lenghu Area in Qinghai. Earth Sci. 2015, 40, 130-144. (In Chinese, with English abstract)

58. Wu, C.L.; Lei, M.; Wu, D.; Li, T.X. Zircon SHRIMP Dating and Genesis of Granites in Wulan Area of Northern Qaidam. Acta Geol. Sin. 2016, 37, 493-516. (In Chinese, with English abstract)

59. Wang, Y.S.; Niu, M.L.; Li, X.C.; Wu, Q.; Han, Y.; Zhao, Q.Q.; Da, L.C. LA-ICP-MS zircon U-Pb dating and Petrogenesis of the Quartz-Diorites from the Guokeshan Area in the Northern margin of the Qaidam basin. Acta Geol. Sin. 2017, 91, 94-110. (In Chinese, with English abstract) [CrossRef]

60. Wang, W.Q.; Liu, C.Y.; Wang, J.Q.; Ma, H.H.; Guan, Y.Z. Characteristics of uranium content and its geological and mineralization significance for the provenance areas, northern northwest China. Earth Sci. Front. 2019, 26, 292-303. (In Chinese, with English abstract)

61. Jiao, Y.Q.; Wu, L.Q.; Peng, Y.B.; Rong, H.; Ji, D.M.; Miao, A.S.; Li, H.L. Sedimentary-tectonic setting of the depositiontype uranium deposits forming in the Paleo-Asian tectonic domain, North China. Earth Sci. Front. 2015, 22, 189-205. (In Chinese, with English abstract)

62. Zhang, L.; Wu, B.L.; Liu, C.Y.; Lei, K.Y.; Hou, H.Q.; Sun, L.; Cun, X.N.; Wang, J.Q. Provenance analysis of the Zhiluo Formation in the Sandstone-hosted Uranium deposits of the Northern Ordos Basin and implications for Uranium Mineralization. Acta Geol. Sin. 2016, 90, 3441-3453. (In Chinese, with English abstract)

63. Yu, D.G.; Wu, R.G.; Chen, P.R. Uranium Geology; Harbin Engineering University Press: Harbin, China, 2005; pp. 1-450. (In Chinese)

64. Hu, R.Z.; Bi, X.W.; Zhou, M.F. Uranium metallogenesis in South China and its relationship to crustal extension during the Cretaceous to Tertiary. Econ. Geol. 2008, 103, 583-598. [CrossRef]

65. Joël, B.; Liu, W.; Etschmann, B.; Mei, Y.; Sherman, D.M.; Testemale, D. A review of the coordination chemistry of hydrothermal systems, or do coordination changes make ore deposits? Chem. Geol. 2016, 447, 219-253.

66. Liu, G.Q.; Zhao, K.D.; Jiang, S.Y.; Chen, W. In-situ sulfur isotope and trace element analysis of pyrite from the Xiwang uranium ore deposit in South China: Implication for ore genesis. J. Geochem. Explor. 2018, 7, 1-17. [CrossRef]

67. Wu, D.H.; Pan, J.Y.; Xia, F.; Huang, G.W.; Lai, J. The mineral chemistry of chlorites and its relationship with uranium mineralization from Huangsha uranium mining area in the Middle Nanling Range, SE China. Minerals 2019, 9, 199. [CrossRef]

68. Jin, R.S.; Miao, P.S.; Sima, X.Z.; Li, J.G.; Zhao, H.L.; Zhao, F.Q.; Fen, X.X.; Chen, L.L.; Zhao, L.J.; Zhu, Q. Structure styles of Mesozoic-Cenozoic U-bearing rock series in Northern China. Acta Geol. Sin. 2016, 90, 2104-2116. [CrossRef]

69. Cheng, Y.H.; Wang, S.Y.; Jin, R.S.; Li, J.G.; Ao, C.; Teng, X.M. Global Miocene tectonics and regional sandstone-style uranium mineralization. Ore Geol. Rev. 2019, 106, 238-250. [CrossRef]

70. Jin, R.S.; Teng, X.M.; Li, X.G.; Si, Q.H.; Wang, W. Genesis of sandstone-type uranium deposits along the northern margin of the Ordos Basin, China. Geosci. Front. 2020, 11, 215-227. [CrossRef] 